\title{
Nerves and Pancreatic Cancer: New Insights into A Dangerous Relationship
}

\author{
Giulia Gasparini ${ }^{1,2} \oplus$, Marta Pellegatta ${ }^{2}$, Stefano Crippa ${ }^{1,3}$, Marco Schiavo Lena ${ }^{4}$, \\ Giulio Belfiori ${ }^{1}$ (D), Claudio Doglioni ${ }^{3,4}$, Carla Taveggia $2, *,+\left(\mathbb{D}\right.$ and Massimo Falconi ${ }^{1,3, *,+}$ \\ 1 Division of Experimental Oncology, Pancreas Translational \& Clinical Research Center, \\ Istituto di Ricovero e Cura a Carattere Scientifico (IRCCS) San Raffaele Scientific Institute, 20132 Milan, Italy \\ 2 Axo-Glial Interaction Unit, INSPE, Division of Neuroscience, Istituto di Ricovero e Cura a Carattere \\ Scientifico (IRCCS) San Raffaele Scientific Institute, 20132 Milan, Italy \\ 3 Department of Pathology, Vita Salute San Raffaele University, 20132 Milan, Italy \\ 4 Pathology Unit, Division of Experimental Oncology, Istituto di Ricovero e Cura a Carattere Scientifico \\ (IRCCS) San Raffaele Scientific Institute, 20132 Milan, Italy \\ * Correspondence: taveggia.carla@hsr.it (C.T.); falconi.massimo@hsr.it (M.F.); \\ Tel.: +39-02-2643-4439 (C.T.); +39-02-2643-6020 (M.F.) \\ + These authors contribute equally to this manuscript.
}

Received: 30 May 2019; Accepted: 24 June 2019; Published: 26 June 2019

check for updates

\begin{abstract}
Perineural invasion (PNI) is defined as the presence of neoplastic cells along nerves and/or within the different layers of nervous fibers: epineural, perineural and endoneural spaces. In pancreatic cancer-particularly in pancreatic ductal adenocarcinoma (PDAC)—PNI has a prevalence between 70 and $100 \%$, surpassing any other solid tumor. PNI has been detected in the early stages of pancreatic cancer and has been associated with pain, increased tumor recurrence and diminished overall survival. Such an early, invasive and recurrent phenomenon is probably crucial for tumor growth and metastasis. PNI is a still not a uniformly characterized event; usually it is described only dichotomously ("present" or "absent"). Recently, a more detailed scoring system for PNI has been proposed, though not specific for pancreatic cancer. Previous studies have implicated several molecules and pathways in PNI, among which are secreted neurotrophins, chemokines and inflammatory cells. However, the mechanisms underlying PNI are poorly understood and several aspects are actively being investigated. In this review, we will discuss the main molecules and signaling pathways implicated in PNI and their roles in the PDAC.
\end{abstract}

Keywords: pancreatic cancer; perineural invasion; neurotrophins; molecular signaling

\section{Introduction}

Pancreatic ductal adenocarcinoma (PDAC), the most common cancer of the exocrine pancreas, is known for its extreme aggressiveness with a 5-year survival rate below 10\% [1] and it is estimated to become the second leading cause of death by $2030[2,3]$.

One of the pathological hallmarks of PDAC is perineural invasion (PNI). Described in pancreatic cancer for the first time in 1944 [4] as a passive process of diffusion along planes of least resistance in the connective nerve sheath [5], it has been since extensively studied in several cancers [6].

Today, PNI is considered a more elaborate process and it is defined as the presence of cancer cells along nerves and/or within the epineural, perineural and endoneural spaces of the neuronal sheath, including cases in which the cells circumscribe at least $33 \%$ of the nerves $[6,7]$.

Although present in several solid tumors, PNI has its highest prevalence in PDAC [8], with a range varying between $70 \%$ and $98 \%$. Accordingly, it has been suggested that PNI could be detected in 
$100 \%$ of cases if enough pathological sections are examined [9-14]. Moreover, PNI is detected in nearly $75 \%$ of the early stages of PDAC and in microscopic PDAC, suggesting that it could represent an early event in cancer progression $[6,7,12,15,16]$.

PNI can therefore be considered a characteristic and pervasive feature of PDAC [17] and such a widespread phenomenon probably has a role in supporting tumor growth. However, despite several new discoveries, a comprehensive and functional understanding of PNI is missing. Understanding the mechanisms by which PNI spreads is critical for developing targeted strategies directed not only towards cancer cells but also to the nerve microenvironment and possibly supporting cells, which likely have a crucial role in promoting tumor growth.

In this review, we will highlight clinical-pathological features of neural invasion as well as recent developments in its molecular comprehension.

\section{Clinical Impact of Perineural Invasion}

Although PNI is almost omnipresent in PDAC patients, a clear consensus in terms of the profound impact of perineural invasion on overall survival, disease free survival, early tumor recurrence is still missing. Numerous studies have reported a correlation between PNI and tumor recurrence and/or patients' survival $[8,9,12,18-24]$; however, few studies failed to show PNI as an independent predictor of tumor recurrence (overall and early) and of patient survival $[25,26]$. These differences are most likely due not only to the retrospective design of the majority of these studies but also to the high variance in histological evaluation of PNI. Indeed, PNI is commonly classified as "present" or "absent" without further sub-classifications. However, at histological level, PNI is highly heterogeneous and it can be classified as intra-pancreatic intratumoral, intra-pancreatic extra tumoral or extra-pancreatic retroperitoneal [9].

A highly debated topic is whether neoplastic spread along nerves might constitute a route for lymph node metastasis [27-29]; this aspect could be particularly relevant for large caliber axons that are often in contact with lymph nodes. Of note, in the absence of both perineural and lymphovascular invasion, the 5-year survival rate for pancreatic adenocarcinoma patients rises to $71 \%$ [21]. Indeed, neoplastic spread creates a route outward the pancreas that may favor both local and systemic recurrence.

Another common symptom in PDAC patients is intractable pain. Pain is a negative prognostic factor for survival [30,31] and was firstly associated with PNI by Zhun Z. [32]. Cancer invasion damages the neural sheath and correlates with increased neural density and remodeling, resulting in both neuropathic and inflammatory pain $[18,33,34]$. Not surprisingly, many molecules that contribute to PNI are also responsible for pain onset. Nerve growth factor (NGF) released by cancer can sensitize sensory nerves and act on TRPV1 (Transient Receptor Potential Vanilloid 1), which in turn correlates with severe pain in patients $[30,35,36]$. Similarly, Glial cell line-Derived Neurotropic Factor (GDNF) and artemin (ARTN), released by cancer, increase TRPV1 expression and thus pain sensibility [37]. Activated TRPV1 then orchestrates the release of substance P and Calcitonin Gene-Related Peptide (CGRP) by nerves: both molecules contribute to neuropathic pain and their expression is increased in PNI [38].

Increased neural invasion also correlates with higher glucose levels in patients [39,40]. Hyperglycemia, present in more than $80 \%$ of patients, [41,42], supports tumor growth, spread and upregulation of NGF, which in turns enhances neural invasion $[43,44]$ and axonogenesis directed at the neoplastic front [39]. Furthermore, in hyperglycemic conditions, nerves degenerate and Schwann cells migration and proliferation are impaired [45,46], making them more vulnerable to neoplastic invasion.

Notably, the anatomic location of the pancreas, surrounded by several neural plexuses [47-49] and the strong neurotropism of PDAC cells (Figure 1), can only partially explain such a high incidence of PNI. Indeed, not all pancreatic cancers have the same degree of neural invasion. PNI is less frequent in Intraductal Papillary Mucinous Neoplasm (IPMNs) with invasive carcinoma and neuroendocrine tumors (NETs) - though it has been recently demonstrated that PNI in NETs is a strong predictor of aggressiveness [50]. 
(a)

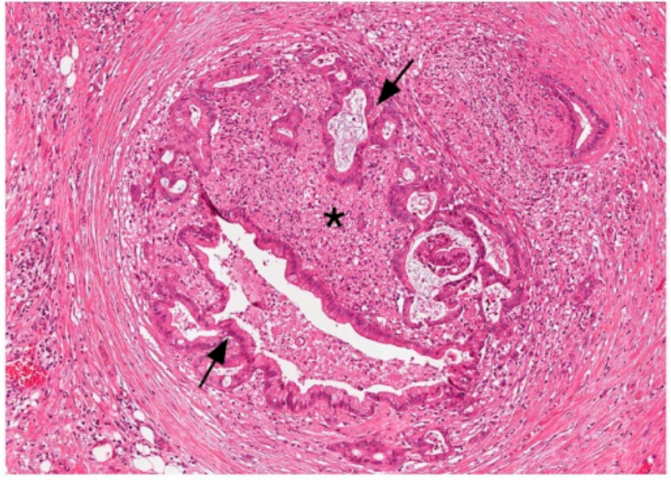

(b)

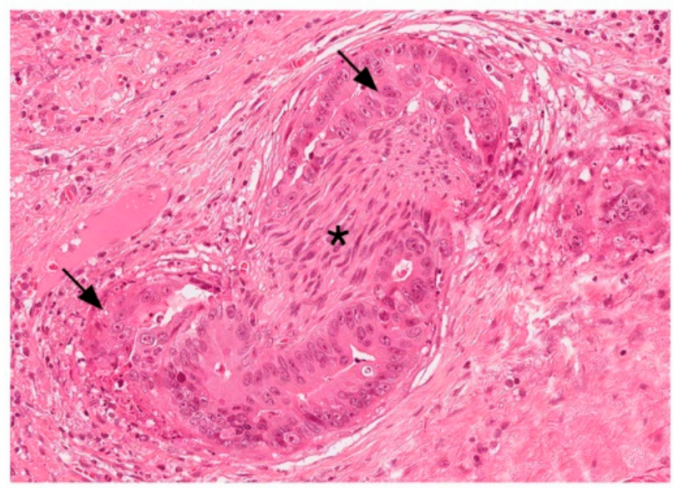

(c)

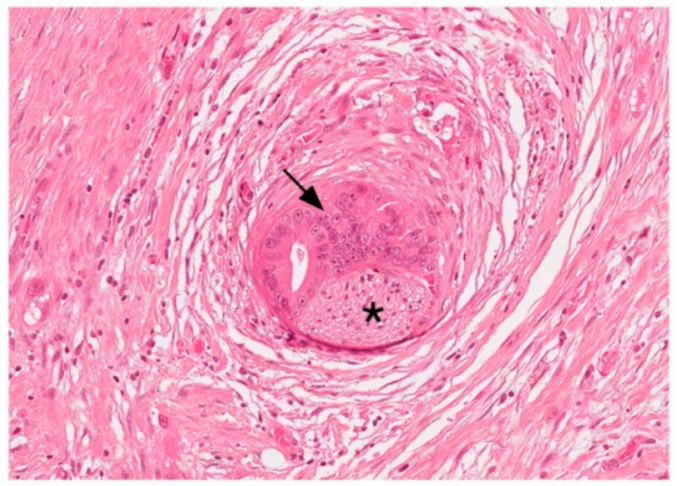

Figure 1. Nerves invaded by pancreatic ductal cancer stained with Hematoxylin and Eosin. (a) Neoplastic glands are growing around and within the nerve fiber. $(\mathbf{b}, \mathbf{c})$ Small diameter nerve fibers surrounded by neoplastic glands. 20× Magnification. Arrows indicate neoplastic glands; asterisks point to nerve fibers.

In this scenario, a recent study has proposed a new method to classify neural invasion in gastrointestinal malignancies with the aim of uniformly characterizing PNI; interestingly, in this study, among all tumors, PDAC emerged as the highest neuroaffin tumor [8].

\section{Pancreatic Innervation}

The Peripheral Nervous System (PNS) collects somatosensory information from the body and regulates physiological functions. Since tumors are not independent organs, they are innervated by peripheral nerves that are part of the tumor microenvironment [51]. Interestingly, nerves can adapt to the ongoing neoplastic processes and establish a bi-directional communication with the tumor, supporting their growth [52]. Further, peripheral nerves are an attracting conduit for neoplastic cells; indeed, cancer cells can be found in all the three different layers of nerves-endoneurium, perineurium, epineurium [17] (Figure 2)-not only superficially tracking along the nerve. The active role of PNS in supporting cancer is evidenced by in vivo preclinical studies. Experimental denervation of different organs in fact impairs tumor formation in animal models of prostate [53], gastric [54] and pancreatic [55] cancer. 


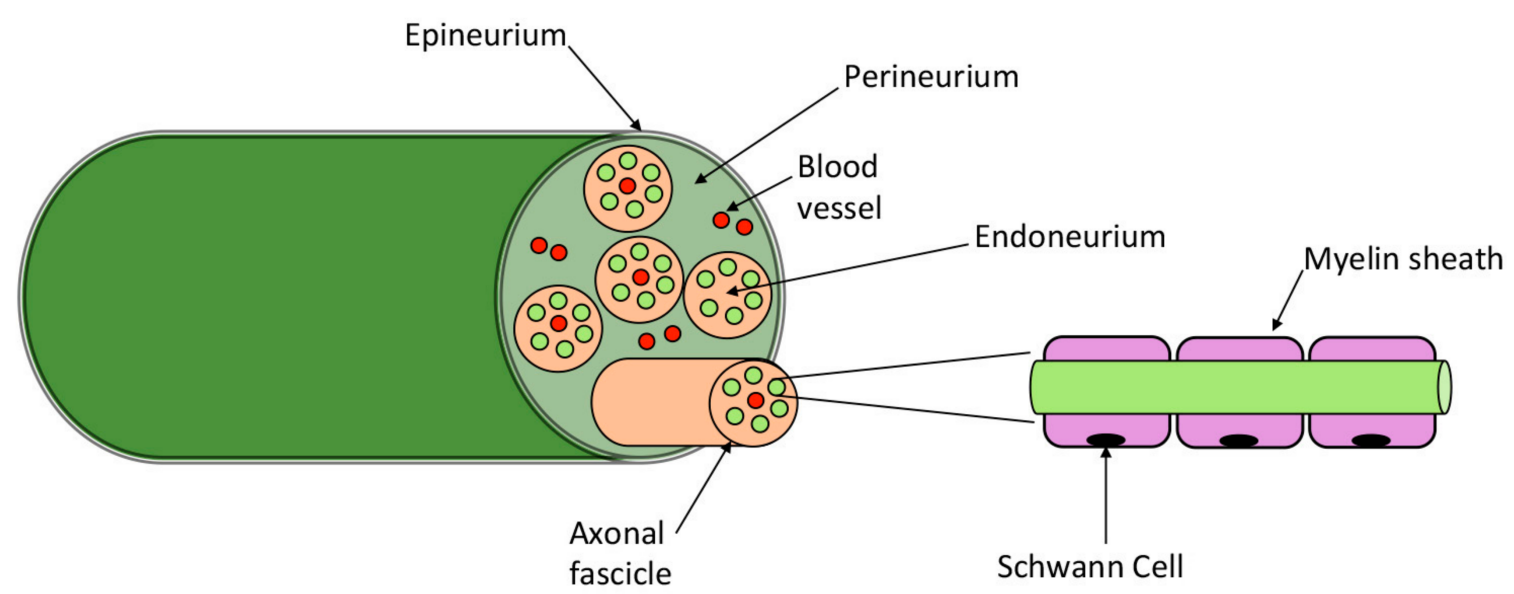

Figure 2. Peripheral nerve structure. The endoneurium is the innermost layer and consists of nerve fibers, composed of axons surrounded by different subtypes of Schwann Cells (myelinating and non-myelinating Schwann cells); it also contains blood vessels, resident macrophages and fibroblasts [56]. The perineurium, which surrounds the endoneurium, is a layer of cylindrical cells tightly interconnected with tight and gap junctions, forming a protective barrier [57]. The epineurium is the outermost layer surrounding several nerve bundles; it includes an elastin and collagen sheath, blood and lymphatic vessels, resident macrophages and mast cells, fibroblasts. The epineurium is itself-innervated by small axons deriving from the endoneurium [58].

The pancreas is a highly innervated organ: the coeliac plexus-the largest autonomic plexuses that lies between the pancreas and the superior mesenteric artery-innervates the head of the pancreas. The coeliac plexus includes right and left coeliac ganglia and the superior mesenteric ganglion. It gives rise to the main structure innervating the pancreas: the pancreaticus capitalis I plexus, derived from the coeliac plexus and the pancreaticus capitalis II plexus, derived from the superior mesenteric ganglion. The splenic plexus instead innervates the body and tail of the pancreas [11].

Both cadaveric studies and more recent imaging analyses with multi-detector row computer tomography have demonstrated a pattern of PNI based on the location of the tumor: tumors of the head expand towards the celiac plexus and ganglion along the pancreaticus capitalis I plexus. Uncinate process cancer instead expand towards the superior mesenteric plexus along inferior pancreaticoduodenal artery plexus, while pancreatic body and tail cancer expands towards the splenic and the celiac plexi $[47-49,59,60]$.

\section{Models to Study Perineural Invasion}

Our understanding of the pathogenesis of PNI has been limited by a lack of effective models allowing a thorough analysis of the complex interactions between nerve, tumor cells and stroma (see BOX 1 for the mostly used models to study PNI).

\subsection{In Vitro Models}

In vitro models rely on co-cultures of pancreatic cancer cells and dorsal root ganglia (DRGs) sensory neurons [61]. This co-culture system allows the analyses of mutual interaction and attraction occurring between these cell types as well the investigation of the mechanisms controlling migration and tropism between cancer cells and nerves [62-64].

An ex vivo model with rat vagal nerves has also been developed [65]. This system allows the study of only invasive cells, as it selects neoplastic clones that, by passing through the nerve, reach the culture plate where they are specifically expanded. This is a valid method for investigating the differences between invasive and non-invasive pancreatic cancer cells. 
More recently, pancreatic organoids have been developed and they represent an innovative model for studying PDAC. Literally "organ-like," organoids are three-dimensional cell cultures growing inside an extracellular matrix that reproduces the tumoral architecture as well as cell-cell and cell-stroma interactions. Importantly, organoids can overcome many limitations found in monolayer cultures, such as tumor heterogeneity, tissue architecture and mechanical signals that in turn impact gene expression [66-68]. In addition, they could be co-cultured with other cell types, such as fibroblasts, immune cells and nerves, allowing the monitor of the interactions between different cell types in physiological conditions as well as in response to drugs [67,69-73].

\subsection{In Vivo Models}

Various mouse models that recapitulate PDAC are also available [74,75]. As highlighted by Demir and colleagues [34], these models should recapitulate neural sprouting, neural hypertrophy, pancreatic neuritis or neural invasion as it occurs in humans, to allow a comprehensive investigation of PNI, although a perfect neuroanatomic similarity has yet to be achieved.

Among the best-characterized models closely recapitulating all PDAC features observed in humans, the KPC mouse model (Pdx-1-Cre; LSL-Kras G12D/+ LSL-Trp53 ${ }^{\mathrm{R} 172 \mathrm{H} /+}$ ) [74] was useful to determine the development of neuroplastic alterations during cancer progression [15]. These mutants develop cancer lesions strongly resembling human PDAC by 10 weeks of age. The carcinomas express CK19, a marker of disease present in almost $90 \%$ of patients [76] and mucin [75]. They also develop liver and lung metastasis similar to patients. Similarly, the KIC mouse model (Pdx1-Cre; LSL-Kras ${ }^{\mathrm{G} 12 \mathrm{D} /+}$; Ink4 $\mathrm{A}^{\mathrm{f} / \mathrm{f}}$ ) [77] was used to study neural plasticity in response to PDAC and its microenvironment [78]. Since in this model IPMN tumors develop between 7 and 12 weeks of age [79], it is considered a valid model to study this form of cancer.

In addition to the above-described animal models, orthotopic models can facilitate the study of angiogenesis and metastasis [80] and, in the setting of PNI, the invasiveness of neoplastic cells along nerves [81]. In these models, cancer cells are injected into the pancreas (or the native organ) after being conjugated to fluorescent reporting proteins. This strategy allows the migratory behavior of cancer cells to be easily followed.

PNI can also be reproduced in several heterotopic models, where neoplastic cells are implanted in areas different from the original tumor site. These models can be useful for studying PNI, since injection of neoplastic cells into murine sciatic nerves [64,82-85] could recapitulate cancer cell migration and the invaded nerves can be collected and processed for further analyses. In addition, heterotopic models could facilitate the assessment of pain related to cancer invasion by performing behavioral tests. Further, they permit the imaging of cancer spreading by magnetic resonance studies [86]. On the contrary, they do not allow the study of early cancer lesions and the interactions between cancer and nerves at pre-neoplastic stages, since already established neoplastic cells are directly injected in the chosen area [34].

Box 1-PNI models

In vitro:

- Co-cultures of DRGs and neoplastic cells: analyses of mutual interactions, tropism and migration. - Ex-vivo model: selection of nerve invasive neoplastic cells and study of the differences with non-invasive tumor cells.

- Organoids: exact recapitulation of the original tumor structure. Can be co-cultured with other cell types to mimic cancer cells-nerve interactions.

In vivo:

- KPC mouse model (LSL-KrasG12D ${ }^{/+}$; LSL-Trp53R172H ${ }^{/+} ; \mathrm{Pdx}-1-\mathrm{Cre}+$ ): it recapitulates the most common human PDAC phenotype. 
- KIC mouse model (Pdx1-Cre; LSL-KrasG12D ${ }^{++}$; Ink4Af/f): study of the accelerated development of PanINs into poorly differentiated PDAC.

- Orthotopic mouse models: study of the migratory behavior of neoplastic cells.

- Heterotopic mouse model: analyses of cancer cell migration and invasiveness.

\section{Nerve-Cancer Microenvironment}

Once cancer cells are inside the nerves, they create the tumor microenvironment. After invasion, tumor cells damage the nerves leading to inflammation and cycles of regenerative processes that are likely exploited by cancer to proliferate $[20,65,83,87,88]$.

Interestingly, different cell types that are physiological components of the pancreas and are involved in tumorigenesis, support nerve-cancer interactions: fibroblasts are modified by cancer and secrete molecules that enhance neuroplasticity [78,89]; immune cells are reprogrammed by the tumor and promote neural invasion [83]; Schwann cells are attracted by cancer and facilitate neural tracking [90-92].

\subsection{Fibroblasts}

Cancer associated fibroblasts (CAFs), the main component of the tumor stroma, derive from bone marrow-derived mesenchymal stem cells, pancreatic stellate cells and stromal resident fibroblasts $[93,94]$ and contribute to cancer invasiveness, angiogenesis and metastasis [93,95-97]. Fibroblasts are also the main cellular constituents of the perineurium [57] and damage to this structure alters blood nerve barrier permeability, thus increasing the risk of tumor cells' invasion.

CAFs may also have a role in promoting neural invasion: they secrete Slit2, an axon guidance molecule, that through Robo1 and Robo2 receptors (via $\mathrm{N}$-cadherin/ $\beta$-catenin signaling) stimulates nerves remodeling and Schwann cells proliferation resulting in increased nerve density in in vitro PDAC models. Additionally, Slit2 expression and CAFs correlate with neural remodeling within human and mouse PDAC [78]. A very recent study proposed that macrophages also participate in the Slit-Robo signaling to control Schwann cells and axons migration after injury. Macrophages secret Slit3, which guides Schwann cells and fibroblasts in forming an appropriate and target-directed nerve bridge, suppressing aberrant migration [98]. Whether this mechanism also promotes nerve remodeling and Schwann cells proliferation in PNI, has yet to be investigated.

Of note, fibroblasts and macrophages present in the cancer microenvironment secrete the cytokine Leukemia Inhibitory Factor (LIF) $[99,100]$, which can increase Schwann cells migration and neural plasticity leading to enhanced neurite outgrowth at least in vitro. Based on the results of this study, LIF has been proposed as a diagnostic marker for pancreatic cancer since it positively correlates with increased intra-tumoral neural density and, in combination with Ca19.9, could distinguish PDAC from other benign pancreatic diseases [89].

\subsection{Pancreatic Stellate Cells}

Stellate cells are myofibroblastic cells that are activated during tumorigenesis and support cancer progression and metastasis [101-103]. These cells could promote neurites' outgrowth and therefore PNI, reinforce cancer cell migration toward nerves and facilitate extracellular matrix (ECM) degradation $[7,30,104,105]$.

\subsection{Immune Cells}

In addition to altering the nerve structure, cancer cells can manipulate immune cells to favor tumor progression and metastasis [106-110]. This presumably also occurs in humans as an increased number of macrophages and PNI have been also reported in samples from PDAC patients [111]. Inflammatory changes have been observed in nerves already in the early stages of PDAC or even before in PanIN lesions, suggesting that nerves might modulate the immune system to support cancer 
progression [51,112], resulting in hypertrophy and hypersensitivity of pancreatic afferents and sensory fibers $[113,114]$.

During tumorigenesis, cancer cells secrete Colony Stimulating Factor (CSF-1) to recruit macrophages; in turn, recruited macrophages release glial derived neurotrophic factor (GDNF) that activates RET (REarranged during Transfection) on cancer cells to promote cancer migration and nerve invasion [83].

In addition to the above-described molecules, the CCL2-CCR2 axis has also been implicated in PNI, as CCR2 deficient mice have reduced PNI and macrophage recruitment to the tumor site [83]. Indeed, it has been shown that CCL2 recruits monocytes and basophils to the inflammatory sites, which in turn express the receptor CCR2. Recent studies have demonstrated that in PNI, Schwann cells secrete CCL2 to recruit bloodstream monocytes, similar to what happens after a nerve injury insult $[56,115,116]$. These monocytes then differentiate into cathepsin B secreting macrophages that disrupt the perineurium, facilitating cancer invasion [117]. Of note, the therapeutic target of this axis is tolerable and can elicit an endogenous anti-tumorigenic immune response [118]. However, there are no indications as to whether this approach could also impact PNI.

\subsection{Schwann Cells}

Schwann cells are the glial cells of the PNS. They originate from neural crest cells and terminally differentiate either in myelinating or non-myelinating cells [115]. Myelinating Schwann cells associate with only one axon ( $\alpha-$ and $\gamma$-motor axons and $\mathrm{A} \alpha-, \mathrm{A} \beta-$ and $\mathrm{A} \delta$-sensory axons) whereas non-myelinating Schwann cells associate with more than one $C$ sensory and autonomic axons forming the structure called Remak Bundles [119]. Regardless of their final commitment, one of the most important roles of Schwann cells is to support neurons' integrity. During cancer invasion, the nerve structure is altered and Schwann cells may have a role in promoting cancer cells' adhesion to axons and thus their invasiveness (123). This phenomenon probably occurs because Schwann cells are plastic cells, as demonstrated by the analysis of the processes regulating nerve regeneration after injury [120].

A growing number of studies suggest that Schwann cells may have an active role in PNI in pancreatic cancer [90]: they have a specific affinity toward pre-neoplastic and neoplastic pancreatic cancer cells [91] and interestingly, after direct contact with cancer cells, Schwann cells actively promote cancer invasiveness and stimulate tumor protrusion and dispersion [92]. Despite the strong contribution of Schwann cells to neural invasion, their functional implications in invasiveness and in the development of pain are yet to be identified.

\section{Molecules and Pathways Involved in PNI}

Since Bockman and colleagues [17] hypothesized the first paracrine mechanisms of signaling between nerves and cancer cells to explain pancreatic cancer nerve-affinity, plenty of molecules have been implicated in PNI. What follows is a brief description of those that are involved in PNI, specifically in PDAC (see also Table 1). 
Table 1. Molecules involved in PNI.

\begin{tabular}{|c|c|c|c|}
\hline Class of Molecules & Molecule & Role in PNI & Refs \\
\hline Axonal guidance molecules & SLIT2-ROBO & Increased expression correlate with PNI and metastasis & {$[80,84]$} \\
\hline Interleukin & LIF & Secreted by CAFs, increases neural plasticity and PNI & [89] \\
\hline \multirow{2}{*}{ Chemokines and receptors } & CCL2-CCR2 & Recruits TAMs to cancer site promoting PNI via GDNF-RET signaling & {$[56,115-118]$} \\
\hline & CXCR1-CX3CL1 & Increases PNI and promotes cancer-nerve adhesion & {$[20,121-123]$} \\
\hline \multirow{3}{*}{ Neurotrophinsand receptors } & NGF-TrkA/p75NTR & Increases growth, proliferation and nerve-cancer affinity & {$[7,18,51,116,124-136]$} \\
\hline & BDNF-TrkB & Increases in vitro proliferation; linked to metastasis & [137-139] \\
\hline & NT3-TrkC & Increases cancer invasiveness, possible role in pain generation & {$[124,125,140,141]$} \\
\hline \multirow{3}{*}{ GDNF family and receptors } & GDNF-GFR $\alpha 1-R E T$ & Increases PNI; TAMs promote PNI through GDNF secretion & {$[2,64,83,142-144]$} \\
\hline & Neurturin-GFR $\alpha 2$ & Increased expression correlates to enhanced PNI & {$[128,145]$} \\
\hline & Artemin-GFR $\alpha 3$ & Promotes cancer migration and PNI & [146-148] \\
\hline \multirow{3}{*}{ Cellular adhesion molecules } & NCAM & Reduces cell—cell adhesion; increased expression contributes to PNI and metastasis & {$[92,149-151]$} \\
\hline & L1CAM & $\begin{array}{l}\text { Mediates homotipic interactions between cancer and nerve increasing PNI; } \\
\text { upregulates MMP2-9 expression facilitating cancer progression }\end{array}$ & [152-156] \\
\hline & MUC1 & Increased levels promote cancer adhesion to nerves and metastasis & {$[88,157-162]$} \\
\hline MMPs & MMP2-9 & Increases PDAC aggressiveness & [163-165] \\
\hline
\end{tabular}




\subsection{Neurotrophic Factors and Neurotrophins' Receptors}

Neurotrophic factors and neurotrophins' receptors enhance neuronal growth and survival $[166,167]$ and play important roles in development, where they act as guidance cues for neurons. In the fully developed nervous system, they are involved in neuronal survival, synaptic plasticity and formation of long-lasting memories.

\subsubsection{Neurotrophins}

The neurotrophins family of growth factors includes Nerve Growth Factor (NGF), Brain-Derived Neurotrophic Factor (BDNF), Neurotrophin-3 (NT-3) and Neurotrophin-4 (NT-4). These molecules bind to different receptors, a high affinity receptor (belonging to the TRK family) and the low affinity receptor p75NTR [168]. The binding of neurotrophins to their specific receptors results in autophosphorylation and the activation of several signaling pathways, among which Ras, phosphatidyl inositol-3 PI3-kinase/AKT, phospholipase C- $\gamma 1$ and MAP kinase $[169,170]$. Whether in addition to mature neurotrophins, their precursors' forms [171] also play a role in PDAC, has yet to be determined.

\section{NGF and TrkA/p75NTR}

Mature NGF is critical for the survival and maintenance of sympathetic and sensory neurons $[172,173]$. Of note, NGF is also produced in pancreatic cancer cells and its receptors TrKA and P75NTR are expressed on both pancreatic cancer cells and nerves, indicating that these molecules could play a role in PNI. Despite previous studies reported P75NTR as inversely correlated to PNI [44], more recently it has been recognized that P75NTR might act as a chemoattractant for cancer cells towards neural tissue to promote PNI [134]. Furthermore, NGF released by cancer cells promotes neuritic growth $[7,62,135,136]$, reduces cancer cells' apoptosis and increases proliferation leading to enhanced cancer aggressiveness $[18,124-126,135]$. Since Schwann cells also release NGF $[90,127]$ it has been suggested that this growth factor might also be involved in enhancing glial cells migration in PNI [128].

As a further confirmation of the role of these molecules in pancreatic cancer, high levels of NGF and TrKA correlate with increased frequency and severity of PNI as well as reduced survival and increased pain in patients $[7,44,124,129-132]$. These events are also frequently associated with lymph node metastases [27]. Of note, NGF depletion by anti-NGF antibodies [112] or gene silencing with gold nanoclusters siRNA [133] reduces progression, metastasis and pain in several pre-clinical models of pancreatic tumors.

\section{BDNF and TrkB}

BDNF supports the survival of existing neurons and promotes the growth of new neurons and synapses $[174,175]$. BDNF and its high affinity receptors are overexpressed in metastatic human PDAC cells [137] but higher BDNF levels do not correlate with increased PNI [138]. Although in vitro studies have shown that BDNF overexpression is linked to increased proliferation and invasion of neoplastic cells and that inhibition of this axis reduced pancreatic cancer cells growth [124], in vivo analyses did not confirm it [139].

\section{NT-3 and TrkC}

NT-3 supports the growth and differentiation of already existing, as well as new, neurons [176]. NT-3 is overexpressed in human PDAC specimens [124] and both NT-3 and its receptor TrkC are highly expressed in intratumoral PDAC nerves [141]. Importantly, blocking NT-3 inhibited the growth of PDAC in a murine xenograft model [125], suggesting that this growth factor may have a role in invasiveness and pain generation [140].

\subsubsection{GDNF family}

The importance of GDNF-RET signaling in perineural invasion in PDAC is well documented $[31,64,129,142,177,178]$. This family of growth factors consists of four members: glial cell 
line-derived neurotropic factor (GDNF), neurturin (NRTN), artemin (ARTN) and persephin (PSPN). They all bind to their cognate GDNF receptor $\alpha$ (GFR $\alpha-G F R \alpha 1$, GFR $\alpha 2$, GFR $\alpha 3$, GFR $\alpha 4$ respectively) forming a complex that signals through the tyrosine kinase receptor RET. These complexes play a role in neural growth, differentiation, survival and nerve repair [179].

\section{GDNF and GFR $\alpha 1$}

GDNF is secreted by nerves and its activity can enhance both cancer cells aggressiveness and neural invasiveness. The role of this complex in PDAC tumors is underlined by the increased expression of both GFR $\alpha 1$ and RET receptors in patients $[64,180,181]$.

It has been suggested that in PDAC, soluble GFR $\alpha 1$, which is released by nerves especially after injury [182], could facilitate the binding between neural GDNF and RET on pancreatic cancer, enhancing PNI [142-144]. In support of the critical role of this pathway in neural invasiveness, reducing GDNF expression or blocking RET activity reduces PNI both in vitro and in vivo [64].

Interestingly, perineural macrophages also express GDNF and tumor associated macrophages (TAMs) express more GDNF than resting macrophages [83]. Of note, GDNF secreted by M2 polarized recruited-perineurial macrophages, activates RET on cancer cells promoting PNI [52,83].

\section{Neurturin and GFR $\alpha 2$}

NRTN and its receptor GFR $\alpha 2$ are important in the normal development of pancreatic parasympathetic innervation [183] and their increased expression correlates with PDAC invasiveness and neural plasticity both in pancreatitis and PDAC [128,145].

\section{Artemin and GFR $\alpha 3$}

ARTN and its receptor GFR $\alpha 3$ are highly expressed in PDAC $[146,147,184]$ and their level correlates with PNI severity. They are also upregulated in chronic pancreatitis after neural damage [146]. Recent studies have hypothesized that Artemin, initiates the migration of pancreatic cancer cells and promotes $\mathrm{PNI}$ and metastasis via NF-KB/CXCR4 signaling [148].

\subsection{Chemokines}

In addition to the CCL2/CCR2 axis we discussed above, several chemokines and their receptors are expressed in PDAC and implicated in cancer invasiveness and progression [185-187]. We will present those mainly involved in PNI.

\section{CXCR1 and CX3CL1 (Fractalkin)}

Both neurons and endothelial cells express CX3CL1 [188-190], the unique ligand for the receptor CX3CR1, which in the central nervous system (CNS) is implicated in neurons-microglia cross talk [191,192]. Interestingly, CX3CR1 is highly expressed in PDAC; moreover, it has been shown that these overexpressing cells migrate and adhere to nerves in response to both soluble and membrane-bound CX3CL1 [20]. In vivo in mice, CX3CR1-positive tumor cells infiltrate peripheral nerves while in PDAC patients, high receptor expression is associated with a prominent neural tropism and local recurrence [20,122].

Notably, both CX3CL1 and CX3CR1 are expressed in PanIN, indicating that these molecules might be involved in early cancer chemotaxis [123] to promote nerve invasion [121].

\subsection{Axonal Guidance Molecules}

During nerve-cancer interaction, chemo-attraction as well as repulsion can occur. In agreement, several studies have analyzed the role of some of these molecules in neural invasion in PDAC.

\section{SLIT2 and ROBO}

Slit2 is a chemorepellent ligand that, by binding to Robo 1 and 2 receptors, participates in axonal growth and branching [193-195] and in Schwann cells' migration [158]. During pancreas development, 
Slit2 guides the correct migration of pancreatic enteric and sensory nerves [196,197] and has a role in preserving pancreatic progenitor identity [198].

In PDAC tumors, Slit2 expression is reduced [84]. Interestingly, restoring Slit2 expression decreases metastatization and neural invasion by reducing chemoattraction between Schwann cells and cancer cells, thus indicating that acting on Slit2 and Robo 1 signaling might prevent PNI [84].

\subsection{Cellular Adhesion Molecules}

Cellular adhesion molecules have important roles in tumor progression and metastasis in several cancers $[199,200]$ and are also likely implicated in enabling cancer-nerve contact.

\subsubsection{Neural Cell Adhesion Molecule 1}

Neurons and developing Schwann cells express NCAM1, which has a crucial role in neural growth, adhesion and regeneration [201-203]. Indeed, after nerve injury dedifferentiated Schwann cells re-express NCAM to support neuronal growth and axonal guidance [204].

Elevated histological expression of NCAM correlates with increased PNI [150] and decreased patient survival [151]. Further, recent studies suggest that upregulation of NCAM1 in Schwann cells could promote cancer cells' migration and dispersion, suggesting a role for NCAM1 in directing the migration of neoplastic cells towards nerves [92]. Moreover, upregulation of NCAM1 has been associated with a reduction in E-cadherin mediated cellular adhesion, thus increasing neoplastic cell migration [149].

\subsubsection{L1 Cell Adhesion Molecule}

L1CAM is a transmembrane neuronal protein important for neuronal migration and differentiation $[152,205,206]$. It is highly expressed in pancreatic cancer cells and its levels of expression correlate with cancer progression, metastasis, pain and PNI [152-156]. It has been recently proposed that homotipic L1CAM-L1CAM interaction between Schwann cells and PDAC cells could promote nerve invasion. These molecules could indeed attract cancer cells to intrapancreatic nerves, upregulate MMP-2 and MMP-9 expression along the axons to facilitate extracellular matrix breakdown and cancer progression [207].

\subsubsection{Mucin 1}

MUC1 is a transmembrane protein regulating both adhesive and antiadhesive properties between cells [208] and it is overexpressed in pancreatic cancer [209-211]. Elevated levels of MUC1 might provide adhesive advantage to cancer cells favoring their survival inside the nerves by binding to Myelin associated glycoprotein on Schwann cells [88]. Further, augmented MUC1 expression correlates to increased metastasis and poor prognosis in humans [157-162]. Interestingly, MUC1 overexpression confers chemoresistance to genotoxic anticancer treatments [212,213].

\subsection{Matrix Metalloproteinases}

Matrix Metalloproteinases (MMPs) are proteolytic enzymes required for the degradation of extracellular matrix; several MMPs are implicated in PDAC [214], in particular high levels of MMP-2/9 in PDAC correlate with metastasis and poor prognosis [215-218]. MMP-2/9 are also expressed in Schwann Cells, where they facilitate neuritic growth and regeneration after injury $[120,219]$ and cleave beta dystroglycan, altering the structure of the axonal compartments [220].

Interestingly, GDNF upregulates MMP-9 expression [163], while NGF-TrKA signaling promotes MMP-2 activity and expression [164]. All these studies further underscore the crucial role of MMPs and neurotrophin signaling in PNI [165].

\subsection{Neurotransmitters}

Neurotransmitter signaling can modulate different aspects of cancer development, such as proliferation, invasion, metastasis [221-224]. (See BOX 2 for autonomic pancreatic innervation $[225,226]$ ). 
Sympathetic signaling via norepinephrine has been shown to increase in vitro neural invasion in DRG neurons by activating the STAT3 $\beta$-adrenergic receptor (signal transducer and activator of transcription 3). Further, they upregulate MMP-2/9 in cancer cells, increasing their motility [227-229]. On the contrary, GABA-the negative regulator of $\beta$-adrenergic signaling-reduces cancer cell proliferation and reverses the pro-growth effects of nicotine in PDAC xenografts models [230-232].

In addition, high adrenergic catecholamines levels promote NGF and BDNF secretion favoring tumor innervation, ensuing further adrenergic signaling in a feed forward loop that promotes tumor growth. Blocking this axis acting on $\beta$-adrenergic receptor 2 or Trk receptor reduces tumor innervation and prolongs mice survival [233]. Accordingly, recent evidence suggests that usage of $\beta$-blockers may increase survival in PDAC patients [234-236].

Of note, ablation of sensory neurons in a mouse model of PDAC reduced the initiation and progression of PDAC [55]; nevertheless, the mechanisms by which denervation alters tumor progression is not yet clear, thus requiring additional studies to better comprehend the complexity of PNI.

While sympathetic signaling promotes PDAC, parasympathetic signaling could inhibit PDAC progression. In animal models, vagotomy accelerates pancreatic cancer development, which is in turn inhibited by cholinergic muscarinic agonists. These most likely downregulate the inflammatory stimuli and inhibit TAMs and TNF $\alpha$ release [237]. Notably, muscarinic signaling via the M3 muscarinic receptor CHRM1 suppresses PDAC growth [238].

Clinical findings have also reinforced these results as vagal nerve activity has a protective role in patients affected by metastatic PDAC [239].

PDAC cells also overexpress the NK-1R receptor, to which Substance $\mathrm{P}-\mathrm{a}$ neuropeptide released by small-diameter sensory C fibers-can bind $[136,240]$. Recently, it has been proposed that substance $\mathrm{P}$ could promote cancer cell proliferation and neural invasion and may also have a role in pain onset [241,242].

Box 2-Pancreatic innervation

In pancreatic cancer there is a decrease in sympathetic fibers, while no difference was noted among parasympathetic fibers $[225,226,243]$.

Sympathetic innervation originates from the sympathetic preganglionic neurons in the lower thoracic segments of the spinal cord; they exit through the sympathetic ganglia without synapse, form splanchnic nerves and terminate on celiac ganglia. Catecholaminergic neurons of these ganglia innervate the intrapancreatic ganglia, islets, blood vessels and the ducts and acini.

Parasympathetic fibers instead originate from the vagus nerve, enter the pancreas through the celiac plexus and end on intrinsic ganglia; they activate parasympathetic post-ganglionic neurons in pancreatic ganglia primarily via signaling on nicotinic acetylcholine receptors.

Sensory information from the pancreas is transmitted to the central nervous system via both vagal and spinal pathways.

\subsection{Translational perspectives}

Given the strong clinical impact, PNI represents an attractive therapeutic target. However, while there are no active clinical trials on PDAC patients, a few pre-clinical studies on animal models have targeted the main molecules involved in PNI (Table 2). For example, it has been shown that NGF inhibition reduces cancer progression [112,133,233], similarly blocking NT-3-TrkC signaling slows PDAC growth in murine models [125]. Moreover, targeting the GDNF-RET axis as well as LIF inhibition reduces PNI both in vitro and in vivo [64,89], while targeting Neurturin impairs PNI and cancer aggressiveness [128]. In addition, it has been recently proposed that radiation might reduce PNI by acting both on neoplastic and nervous cells [244]. Though promising, all these targets have been investigated only in pre-clinical settings and further studies are needed to translate their feasibility in clinical practice. 
Table 2. Molecules involved in PNI-translational perspectives.

\begin{tabular}{|c|c|c|c|}
\hline Target & Intervention & Effect & Refs \\
\hline LIF & Antibodies against LIF & Reduction of neural density and nerve infiltration & [89] \\
\hline CCR2 & Inhibition of CCR2 in combination with FOLFIRINOX & Safe and feasible; not yet investigated specifically for PNI & [118] \\
\hline NGF & Depletion by anti-NGF antibodies; gene silencing with siRNA & Reduction in progression, neural invasion, metastasis and pain & {$[112,133,233]$} \\
\hline NT3-TrkC & Antibodies against NT3 & Slower PDAC growth & [125] \\
\hline GDNF-GFR $\alpha 1-R E T$ & GFR $\alpha 1$ silencing by siRNA, antibodies against RET. Radiation & $\begin{array}{l}\text { Block endoneural macrophages activation and cancer } \\
\text { invasiveness. Decrease GDNF secretion }\end{array}$ & {$[64,244]$} \\
\hline Neurturin-GFR $\alpha 2$ & Depletion by anti-NRTN antibodies & Decrease in neural density & [128] \\
\hline $\begin{array}{l}\text { } \beta 2 \text { adrenergic receptor } \\
\text { (ADRB2) }\end{array}$ & Pharmacological blockage & $\begin{array}{l}\text { Decrease cancer-nerve interactions; } \\
\text { diminish neurotrophins secretion }\end{array}$ & [233] \\
\hline
\end{tabular}




\section{Conclusions and Future Directions}

PNI is a complex phenomenon that involves multi-directional communication between nerves, cancer and cells of the neoplastic microenvironment. The interactions occurring in PNI reciprocally support nerve and cancer growth, dispersion and migration. Interestingly, the neuroplasticity events of PDAC partly resemble the physiological mechanisms occurring after nerve injury. Thus, a combined effort between scientists and experts in all these fields might help in unraveling the pathological mechanisms underlying PNI and possibly develop new therapeutic approaches for this devastating cancer.

Author Contributions: Conceptualization, G.G.; Resources, G.B., M.S.L., C.D.; Writing-original draft preparation G.G., M.P., S.C.; Writing-review and editing C.T., M.F.; Supervision C.T., M.F.

Funding: This research received no external funding.

Acknowledgments: We are grateful to the Gioja Bianca Costanza Fund to support the training of Giulia Gasparini and Giulio Belfiori.

Conflicts of Interest: The authors declare no conflict of interest.

\section{References}

1. Bray, F.; Ferlay, J.; Soerjomataram, I.; Siegel, R.L.; Torre, L.A.; Jemal, A. Global cancer statistics 2018: Globocan estimates of incidence and mortality worldwide for 36 cancers in 185 countries. Cancer J. Clin. 2018, 68, 394-424. [CrossRef] [PubMed]

2. Rahib, L.; Smith, B.D.; Aizenberg, R.; Rosenzweig, A.B.; Fleshman, J.M.; Matrisian, L.M. Projecting cancer incidence and deaths to 2030: The unexpected burden of thyroid, liver and pancreas cancers in the United States. Cancer Res. 2014, 74, 2913-2921. [CrossRef] [PubMed]

3. Maisonneuve, P. Epidemiology and burden of pancreatic cancer. Presse Med. 2019, 48, e113-e123. [CrossRef] [PubMed]

4. Drapiewski, J.F. Carcinoma of the Pancreas: A Study of Neoplastic Invasion of Nerves and its Possible Clinical Significance. Am. J. Clin. Pathol. 1944, 14, 549-556. [CrossRef]

5. Batsakis, J.G. Nerves and neurotropic carcinomas. Ann. Otol. Rhinol. Laryngol. 1985, 94, 426-427.

6. Liebig, C.; Ayala, G.; Wilks, J.A.; Berger, D.H.; Albo, D. Perineural invasion in cancer: A review of the literature. Cancer 2009, 115, 3379-3391. [CrossRef]

7. Demir, I.E.; Ceyhan, G.O.; Liebl, F.; D’Haese, J.G.; Maak, M.; Friess, H. Neural invasion in pancreatic cancer: The past, present and future. Cancers 2010, 2, 1513-1527. [CrossRef]

8. Liebl, F.; Demir, I.E.; Mayer, K.; Schuster, T.; D’Haese, J.G.; Becker, K.; Langer, R.; Bergmann, F.; Wang, K.; Rosenberg, R.; et al. The Impact of Neural Invasion Severity in Gastrointestinal Malignancies: A Clinicopathological Study. Cancer Cell 2016, 31, 342-354. [CrossRef]

9. Schorn, S.; Demir, I.E.; Haller, B.; Scheufele, F.; Reyes, C.M.; Tieftrunk, E.; Sargut, M.; Goess, R.; Friess, H.; Ceyhan, G.O. The influence of neural invasion on survival and tumor recurrence in pancreatic ductal adenocarcinoma-A systematic review and meta-analysis. Surg. Oncol. 2017, 26, 105-115. [CrossRef]

10. Chatterjee, D.; Katz, M.H.; Rashid, A.; Wang, H.; Iuga, A.C.; Varadhachary, G.R.; Wolff, R.A.; Lee, J.E.; Pisters, P.W.; Crane, C.H.; et al. Perineural and Intraneural Invasion in Posttherapy Pancreaticoduodenectomy Specimens Predicts Poor Prognosis in Patients with Pancreatic Ductal Adenocarcinoma. Am. J. Surg. Pathol. 2012, 36, 409-417. [CrossRef]

11. Pour, P.M.; Bell, R.H.; Batra, S.K. Neural invasion in the staging of pancreatic cancer. Pancreas 2003, 26, 322-325. [CrossRef] [PubMed]

12. Hirai, I.; Kimura, W.; Ozawa, K.; Kudo, S.; Suto, K.; Kuzu, H.; Fuse, A. Perineural invasion in pancreatic cancer. Pancreas 2002, 24, 15-25. [CrossRef] [PubMed]

13. Ozaki, H.; Hiraoka, T.; Mizumoto, R.; Matsuno, S.; Matsumoto, Y.; Nakayama, T.; Tsunoda, T.; Suzuki, T.; Monden, M.; Saitoh, Y.; et al. The prognostic significance of lymph node metastasis and intrapancreatic perineural invasion in pancreatic cancer after curative resection. Surg. Today 1999, 29, 16-22. [CrossRef] [PubMed] 
14. Takahashi, T.; Ishikura, H.; Motohara, T.; Okushiba, S.-I.; Dohke, M.; Katoh, H. Perineural invasion by ductal adenocarcinoma of the pancreas. J. Surg. Oncol. 1997, 65, 164-170. [CrossRef]

15. Stopczynski, R.E.; Normolle, D.P.; Hartman, D.J.; Ying, H.; DeBerry, J.J.; Bielefeldt, K.; Rhim, A.D.; DePinho, R.A.; Albers, K.M.; Davis, B.M. Neuroplastic Changes Occur Early in the Development of Pancreatic Ductal Adenocarcinoma. Cancer Res. 2014, 74, 1718-1727. [CrossRef] [PubMed]

16. Kimura, W.; Morikane, K.; Esaki, Y.; Chan, W.C.; Pour, P.M. Histologic and biologic patterns of microscopic pancreatic ductal adenocarcinomas detected incidentally at autopsy. Cancer 1998, 82, 1839-1849. [CrossRef]

17. Bockman, D.E.; Büchler, M.; Beger, H.G. Interaction of pancreatic ductal carcinoma with nerves leads to nerve damage. Gastroenterology 1994, 107, 219-230. [CrossRef]

18. Bapat, A.A.; Hostetter, G.; Von Hoff, D.D.; Han, H. Perineural invasion and associated pain in pancreatic cancer. Nat. Rev. Cancer 2011, 11, 695-707. [CrossRef]

19. Tummers, W.S.; Groen, J.V.; Sibinga Mulder, B.G.; Farina-Sarasqueta, A.; Morreau, J.; Putter, H.; van de Velde, C.J.; Vahrmeijer, A.L.; Bonsing, B.A.; Mieog, J.S.; et al. Impact of resection margin status on recurrence and survival in pancreatic cancer surgery. BJS 2019, 11115. [CrossRef]

20. Marchesi, F.; Piemonti, L.; Fedele, G.; Destro, A.; Roncalli, M.; Albarello, L.; Doglioni, C.; Anselmo, A.; Doni, A.; Bianchi, P.; et al. The Chemokine Receptor CX3CR1 Is Involved in the Neural Tropism and Malignant Behavior of Pancreatic Ductal Adenocarcinoma. Cancer Res. 2008, 68, 9060-9069. [CrossRef]

21. Chen, J.W.C.; Bhandari, M.; Astill, D.S.; Wilson, T.G.; Kow, L.; Brooke-Smith, M.; Toouli, J.; Padbury, R.T.A. Predicting patient survival after pancreaticoduodenectomy for malignancy: Histopathological criteria based on perineural infiltration and lymphovascular invasion. HPB 2010, 12, 101-108. [CrossRef] [PubMed]

22. Perini, M.V.; Montagnini, A.L.; Jukemura, J.; Penteado, S.; Abdo, E.E.; Patzina, R.; Cecconello, I.; Cunha, J.E.M. Clinical and pathologic prognostic factors for curative resection for pancreatic cancer. HPB 2008, 10, 356-362. [CrossRef] [PubMed]

23. Seino, T.; Kawasaki, S.; Shimokawa, M.; Tamagawa, H.; Toshimitsu, K.; Fujii, M.; Ohta, Y.; Matano, M.; Nanki, K.; Kawasaki, K.; et al. Human Pancreatic Tumor Organoids Reveal Loss of Stem Cell Niche Factor Dependence during Disease Progression. Cell Stem Cell 2018, 22, 454-467. [CrossRef] [PubMed]

24. Iwasaki, T.; Hiraoka, N.; Ino, Y.; Nakajima, K.; Kishi, Y.; Nara, S.; Esaki, M.; Shimada, K.; Katai, H. Reduction of intrapancreatic neural density in cancer tissue predicts poorer outcome in pancreatic ductal carcinoma. Cancer Sci. 2019, 110, 1491-1502. [CrossRef] [PubMed]

25. Groot, V.P.; Gemenetzis, G.; Blair, A.B.; Rivero-Soto, R.J.; Yu, J.; Javed, A.A.; Burkhart, R.A.; Rinkes, I.H.M.B.; Molenaar, I.Q.; Cameron, J.L.; et al. Defining and Predicting Early Recurrence in 957 Patients with Resected Pancreatic Ductal Adenocarcinoma. Ann. Surg. 2019, 269, 1154-1162. [CrossRef] [PubMed]

26. Groot, V.P.; Rezaee, N.; Wu, W.; Cameron, J.L.; Fishman, E.K.; Hruban, R.H.; Weiss, M.J.; Zheng, L.; Wolfgang, C.L.; He, J. Patterns, Timing and Predictors of Recurrence Following Pancreatectomy for Pancreatic Ductal Adenocarcinoma. Ann. Surg. 2018, 267, 936-945. [CrossRef]

27. Kayahara, M.; Nakagawara, H.; Kitagawa, H.; Ohta, T. The nature of neural invasion by pancreatic cancer. Pancreas 2007, 35, 218-223. [CrossRef]

28. Cheng, P.; Jin, G.; Hu, X.; Shi, M.; Zhang, Y.; Liu, R.; Zhou, Y.; Shao, C.; Zheng, J.; Zhu, M. Analysis of tumor-induced lymphangiogenesis and lymphatic vessel invasion of pancreatic carcinoma in the peripheral nerve plexus. Cancer Sci. 2012, 103, 1756-1763. [CrossRef]

29. Fink, D.M.; Steele, M.M.; Hollingsworth, M.A. The lymphatic system and pancreatic cancer. Cancer Lett. 2016, 381, 217-236. [CrossRef]

30. Ceyhan, G.O.; Bergmann, F.; Kadihasanoglu, M.; Altintas, B.; Demir, I.E.; Hinz, U.; Müller, M.W.; Giese, T.; Büchler, M.W.; Giese, N.A.; et al. Pancreatic Neuropathy and Neuropathic Pain-A Comprehensive Pathomorphological Study of 546 Cases. Gastroenterology 2009, 136, 177-186. [CrossRef]

31. Demir, I.E.; Friess, H.; Ceyhan, G.O. Nerve-cancer interactions in the stromal biology of pancreatic cancer. Front. Physiol. 2012, 3, 97. [CrossRef]

32. Di Mola, F.F.; Zhu, Z.; Graber, H.U.; Friess, H.; Korc, M.; Büchler, M.W.; Zimmermann, A. Nerve Growth Factor Expression Correlates with Perineural Invasion and Pain in Human Pancreatic Cancer. J. Clin. Oncol. 2017, 17, 2419.

33. Di Mola, F.F.; di Sebastiano, P. Pain and pain generation in pancreatic cancer. Langenbeck's Arch. Surg. 2008, 393, 919-922. [CrossRef] [PubMed] 
34. Demir, I.E.; Friess, H.; Ceyhan, G.O. Neural plasticity in pancreatitis and pancreatic cancer. Nat. Rev. Gastroenterol. Hepatol. 2015, 12, 649-659. [CrossRef] [PubMed]

35. Zhu, Y.; Colak, T.; Shenoy, M.; Liu, L.; Pai, R.; Li, C.; Mehta, K.; Pasricha, P.J. Nerve Growth Factor Modulates TRPV1 Expression and Function and Mediates Pain in Chronic Pancreatitis. Gastroenterology 2011, 141, 370-377. [CrossRef] [PubMed]

36. Hartel, M.; di Mola, F.F.; Selvaggi, F.; Mascetta, G.; Wente, M.N.; Felix, K.; Giese, N.A.; Hinz, U.; Di Sebastiano, P.; Büchler, M.W.; et al. Vanilloids in pancreatic cancer: Potential for chemotherapy and pain management. Gut 2006, 55, 519-528. [CrossRef] [PubMed]

37. Malin, S.A.; Molliver, D.C.; Koerber, H.R.; Cornuet, P.; Frye, R.; Albers, K.M.; Davis, B.M. Glial Cell Line-Derived Neurotrophic Factor Family Members Sensitize Nociceptors In Vitro and Produce Thermal Hyperalgesia In Vivo. J. Neurosci. 2006, 26, 8588-8599. [CrossRef] [PubMed]

38. Schweizerhof, M.; Stösser, S.; Kurejova, M.; Njoo, C.; Gangadharan, V.; Agarwal, N.; Schmelz, M.; Bali, K.K.; Michalski, C.W.; Brugger, S.; et al. Hematopoietic colony-stimulating factors mediate tumor-nerve interactions and bone cancer pain. Nat. Med. 2009, 15, 802-807. [CrossRef]

39. Li, J.; Ma, Q.; Liu, H.; Guo, K.; Li, F.; Li, W.; Han, L.; Wang, F.; Wu, E. Relationship between Neural Alteration and Perineural Invasion in Pancreatic Cancer Patients with Hyperglycemia. PLoS ONE 2011, 6, e17385. [CrossRef]

40. Li, J.; Ma, J.; Han, L.; Xu, Q.; Lei, J.; Duan, W.; Li, W.; Wang, F.; Wu, E.; Ma, Q.; et al. Hyperglycemic tumor microenvironment induces perineural invasion in pancreatic cancer. Cancer Biol. Ther. 2015, 16, $912-921$. [CrossRef]

41. Pannala, R.; Basu, A.; Petersen, G.M.; Chari, S.T. New-onset diabetes: A potential clue to the early diagnosis of pancreatic cancer. Lancet Oncol. 2009, 10, 88-95. [CrossRef]

42. Meier, J.J.; Giese, A. Diabetes associated with pancreatic diseases. Curr. Opin. Gastroenterol. 2015, 31, 400-406. [CrossRef] [PubMed]

43. Larrieta, M.E.; Vital, P.; Mendoza-Rodríguez, A.; Cerbón, M.; Hiriart, M. Nerve growth factor increases in pancreatic beta cells after streptozotocin-induced damage in rats. Exp. Biol. Med. 2006, 231, 396-402. [CrossRef] [PubMed]

44. Dang, C.; Zhang, Y.; Ma, Q.; Shimahara, Y. Expression of nerve growth factor receptors is correlated with progression and prognosis of human pancreatic cancer. J. Gastroenterol. Hepatol. 2006, 21, 850-858. [CrossRef] [PubMed]

45. Zochodne, D.W. Diabetes mellitus and the peripheral nervous system: Manifestations and mechanisms. Muscle Nerve 2007, 36, 144-166. [CrossRef] [PubMed]

46. Gumy, L.F.; Bampton, E.T.W.; Tolkovsky, A.M. Hyperglycaemia inhibits Schwann cell proliferation and migration and restricts regeneration of axons and Schwann cells from adult murine DRG. Mol. Cell. Neurosci. 2008, 37, 298-311. [CrossRef] [PubMed]

47. Yi, S.Q.; Miwa, K.; Ohta, T.; Kayahara, M.; Kitagawa, H.; Tanaka, A.; Shimokawa, T.; Akita, K.; Tanaka, S. Innervation of the pancreas from the perspective of perineural invasion of pancreatic cancer. Pancreas 2003, 27, 225-229. [CrossRef]

48. Makino, I.; Kitagawa, H.; Ohta, T.; Nakagawara, H.; Tajima, H.; Ohnishi, I.; Takamura, H.; Tani, T.; Kayahara, M. Nerve plexus invasion in pancreatic cancer: Spread patterns on histopathologic and embryological analyses. Pancreas 2008, 37, 358-365. [CrossRef]

49. Patel, B.N.; Olcott, E.; Jeffrey, R.B. Extrapancreatic perineural invasion in pancreatic adenocarcinoma. Abdom. Radiol. 2018, 43, 323-331. [CrossRef]

50. Partelli, S.; Muffatti, F.; Rancoita, P.M.V.; Andreasi, V.; Balzano, G.; Crippa, S.; Doglioni, C.; Rubini, C.; Zamboni, G.; Falconi, M. The size of well differentiated pancreatic neuroendocrine tumors correlates with Ki67 proliferative index and is not associated with age. Dig. Liver Dis. 2019, 51, 735-740. [CrossRef]

51. Saloman, J.L.; Albers, K.M.; Rhim, A.D.; Davis, B.M. Can Stopping Nerves, Stop Cancer? Trends Neurosci. 2016, 39, 880-889. [CrossRef] [PubMed]

52. Amit, M.; Na'ara, S.; Gil, Z. Mechanisms of cancer dissemination along nerves. Nat. Rev. Cancer 2016, 16, 399-408. [CrossRef] [PubMed]

53. Magnon, C.; Hall, S.J.; Lin, J.; Xue, X.; Gerber, L.; Freedland, S.J.; Frenette, P.S. Autonomic Nerve Development Contributes to Prostate Cancer Progression. Science 2013, 341, 1236361. [CrossRef] [PubMed] 
54. Zhao, C.-M.; Hayakawa, Y.; Kodama, Y.; Muthupalani, S.; Westphalen, C.B.; Andersen, G.T.; Flatberg, A.; Johannessen, H.; Friedman, R.A.; Renz, B.W.; et al. Denervation suppresses gastric tumorigenesis. Sci. Transl. Med. 2014, 6, ra115-ra250. [CrossRef] [PubMed]

55. Saloman, J.L.; Albers, K.M.; Li, D.; Hartman, D.J.; Crawford, H.C.; Muha, E.A.; Rhim, A.D.; Davis, B.M. Ablation of sensory neurons in a genetic model of pancreatic ductal adenocarcinoma slows initiation and progression of cancer. Proc. Natl. Acad. Sci. USA 2016, 113, 3078-3083. [CrossRef] [PubMed]

56. Jessen, K.R.; Mirsky, R. The repair Schwann cell and its function in regenerating nerves. J. Physiol. 2016, 594, 3521-3531. [CrossRef]

57. Bunge, M.B.; Wood, P.M.; Tynan, L.B.; Bates, M.L.; Sanes, J.R. Perineurium originates from fibroblasts: Demonstration in vitro with a retroviral marker. Science 1989, 243, 229-231. [CrossRef]

58. Stolinski, C. Structure and composition of the outer connective tissue sheaths of peripheral nerve. J. Anat. 1995, 186 Pt 1, 123-130.

59. Deshmukh, S.D.; Willmann, J.K.; Jeffrey, R.B. Pathways of extrapancreatic perineural invasion by pancreatic adenocarcinoma: Evaluation with 3D volume-rendered MDCT imaging. Am. J. Roentgenol. 2010, 194, 668-674. [CrossRef]

60. Mochizuki, K.; Gabata, T.; Kozaka, K.; Hattori, Y.; Zen, Y.; Kitagawa, H.; Kayahara, M.; Ohta, T.; Matsui, O. MDCT findings of extrapancreatic nerve plexus invasion by pancreas head carcinoma: Correlation with en bloc pathological specimens and diagnostic accuracy. Eur. Radiol. 2010, 20, 1757-1767. [CrossRef]

61. Ayala, G.E.; Wheeler, T.M.; Shine, H.D.; Schmelz, M.; Frolov, A.; Chakraborty, S.; Rowley, D. In Vitro dorsal root ganglia and human prostate cell line interaction: Redefining perineural invasion in prostate cancer. Prostate 2001, 49, 213-223. [CrossRef] [PubMed]

62. Dai, H.; Li, R.; Wheeler, T.; Ozen, M.; Ittmann, M.; Anderson, M.; Wang, Y.; Rowley, D.; Younes, M.; Ayala, G.E. Enhanced survival in perineural invasion of pancreatic cancer: An In Vitro approach. Hum. Pathol. 2007, 38, 299-307. [CrossRef] [PubMed]

63. Malin, S.A.; Davis, B.M.; Molliver, D.C. Production of dissociated sensory neuron cultures and considerations for their use in studying neuronal function and plasticity. Nat. Protoc. 2007, 2, 152-160. [CrossRef] [PubMed]

64. Gil, Z.; Cavel, O.; Kelly, K.; Brader, P.; Rein, A.; Gao, S.P.; Carlson, D.L.; Shah, J.P.; Fong, Y.; Wong, R.J. Paracrine regulation of pancreatic cancer cell invasion by peripheral nerves. J. Natl. Cancer Inst. 2010, 102, 107-118. [CrossRef] [PubMed]

65. Abiatari, I.; DeOliveira, T.; Kerkadze, V.; Schwager, C.; Esposito, I.; Giese, N.A.; Huber, P.; Bergman, F.; Abdollahi, A.; Friess, H.; et al. Consensus transcriptome signature of perineural invasion in pancreatic carcinoma. Mol. Cancer Ther. 2009, 8, 1494-1504. [CrossRef] [PubMed]

66. Baker, L.A.; Tiriac, H.; Clevers, H.; Tuveson, D.A. Modeling Pancreatic Cancer with Organoids. Trends Cancer 2016, 2, 176-190. [CrossRef] [PubMed]

67. Tsai, S.; McOlash, L.; Palen, K.; Johnson, B.; Duris, C.; Yang, Q.; Dwinell, M.B.; Hunt, B.; Evans, D.B.; Gershan, J.; et al. Development of primary human pancreatic cancer organoids, matched stromal and immune cells and 3D tumor microenvironment models. BMC Cancer 2018, 18, 335. [CrossRef] [PubMed]

68. Romero-Calvo, I.; Weber, C.R.; Ray, M.; Brown, M.; Kirby, K.; Nandi, R.K.; Long, T.M.; Sparrow, S.M.; Ugolkov, A.; Qiang, W.; et al. Human Organoids Share Structural and Genetic Features with Primary Pancreatic Adenocarcinoma Tumors. Mol. Cancer Res. 2019, 17, 70-83. [CrossRef] [PubMed]

69. Broutier, L.; Andersson-Rolf, A.; Hindley, C.J.; Boj, S.F.; Clevers, H.; Koo, B.K.; Huch, M. Culture and establishment of self-renewing human and mouse adult liver and pancreas 3D organoids and their genetic manipulation. Nat. Protoc. 2016, 11, 1724-1743. [CrossRef]

70. Sachs, N.; de Ligt, J.; Kopper, O.; Gogola, E.; Bounova, G.; Weeber, F.; Balgobind, A.V.; Wind, K.; Gracanin, A.; Begthel, H.; et al. A Living Biobank of Breast Cancer Organoids Captures Disease Heterogeneity. Cell 2018, 172, 373-386.e10. [CrossRef]

71. Boj, S.F.; Hwang, C.I.; Baker, L.A.; Chio, I.I.C.; Engle, D.D.; Corbo, V.; Jager, M.; Ponz-Sarvise, M.; Tiriac, H.; Spector, M.S.; et al. Organoid models of human and mouse ductal pancreatic cancer. Cell 2015, 160, 324-338. [CrossRef] [PubMed]

72. Tiriac, H.; Belleau, P.; Engle, D.D.; Plenker, D.; Deschênes, A.; Somerville, T.D.D.; Froeling, F.E.M.; Burkhart, R.A.; Denroche, R.E.; Jang, G.H.; et al. Organoid profiling identifies common responders to chemotherapy in pancreatic cancer. Cancer Discov. 2018, 8, 1112-1129. [CrossRef] [PubMed] 
73. Neal, J.T.; Li, X.; Zhu, J.; Giangarra, V.; Grzeskowiak, C.L.; Ju, J.; Liu, I.H.; Chiou, S.H.; Salahudeen, A.A.; Smith, A.R.; et al. Organoid Modeling of the Tumor Immune Microenvironment. Cell 2018, 175, 1972-1988. [CrossRef] [PubMed]

74. Hingorani, S.R.; Wang, L.; Multani, A.S.; Combs, C.; Deramaudt, T.B.; Hruban, R.H.; Rustgi, A.K.; Chang, S.; Tuveson, D.A. Trp53R172H and KrasG12D cooperate to promote chromosomal instability and widely metastatic pancreatic ductal adenocarcinoma in mice. Cancer Cell 2005, 7, 469-483. [CrossRef] [PubMed]

75. Herreros-Villanueva, M.; Hijona, E.; Cosme, A.; Bujanda, L. Mouse models of pancreatic cancer. World J. Gastroenterol. 2012, 18, 1286. [CrossRef] [PubMed]

76. Bouwens, L. Cytokeratins and cell differentiation in the pancreas. J. Pathol. 1998, 184, 234-239. [CrossRef]

77. Aguirre, A.J.; Bardeesy, N.; Sinha, M.; Lopez, L.; Tuveson, D.A.; Horner, J.; Redston, M.S.; DePinho, R.A. Activated Kras and Ink4a/Arf deficiency cooperate to produce metastatic pancreatic ductal adenocarcinoma. Genes Dev. 2003, 17, 3112-3126. [CrossRef]

78. Secq, V.; Leca, J.; Bressy, C.; Guillaumond, F.; Skrobuk, P.; Nigri, J.; Lac, S.; Lavaut, M.N.; Bui, T.T.; Thakur, A.K.; et al. Stromal SLIT2 impacts on pancreatic cancer-associated neural remodeling. Cell Death Dis. 2015, 6, e1592. [CrossRef]

79. Bardeesy, N.; Cheng, K.H.; Berger, J.H.; Chu, G.C.; Pahler, J.; Olson, P.; Hezel, A.F.; Horner, J.; Lauwers, G.Y.; Hanahan, D.; et al. Smad4 is dispensable for normal pancreas development yet critical in progression and tumor biology of pancreas cancer. Genes Dev. 2006, 20, 3130-3146. [CrossRef]

80. Eibl, G.; Reber, H.A. A xenograft nude mouse model for perineural invasion and recurrence in pancreatic cancer. Pancreas 2005, 31, 258-262. [CrossRef]

81. Yao, J.; Zhang, L.-L.; Huang, X.-M.; Li, W.-Y.; Gao, S.-G. Pleiotrophin and N-syndecan promote perineural invasion and tumor progression in an orthotopic mouse model of pancreatic cancer. World J. Gastroenterol. 2017, 23, 3907-3914. [CrossRef] [PubMed]

82. Deborde, S.; Yu, Y.; Marcadis, A.; Chen, C.-H.; Fan, N.; Bakst, R.L.; Wong, R.J. An In Vivo Murine Sciatic Nerve Model of Perineural Invasion. J. Vis. Exp. 2018, 134, e56857. [CrossRef] [PubMed]

83. Cavel, O.; Shomron, O.; Shabtay, A.; Vital, J.; Trejo-Leider, L.; Weizman, N.; Krelin, Y.; Fong, Y.; Wong, R.J.; Amit, M.; et al. Endoneurial macrophages induce perineural invasion of pancreatic cancer cells by secretion of GDNF and activation of RET tyrosine kinase receptor. Cancer Res. 2012, 72, 5733-5743. [CrossRef] [PubMed]

84. Gohrig, A.; Detjen, K.M.; Hilfenhaus, G.; Korner, J.L.; Welzel, M.; Arsenic, R.; Schmuck, R.; Bahra, M.; Wu, J.Y.; Wiedenmann, B.; et al. Axon guidance factor SLIT2 inhibits neural invasion and metastasis in pancreatic cancer. Cancer Res. 2014, 74, 1529-1540. [CrossRef] [PubMed]

85. Imoto, A.; Mitsunaga, S.; Inagaki, M.; Aoyagi, K.; Sasaki, H.; Ikeda, M.; Nakachi, K.; Higuchi, K.; Ochiai, A. Neural invasion induces cachexia via astrocytic activation of neural route in pancreatic cancer. Int. J. Cancer 2012, 131, 2795-2807. [CrossRef] [PubMed]

86. Bakst, R.L.; Wong, R.J. Mechanisms of Perineural Invasion. J. Neurol. Surg. Part B Skull Base 2016, 77, 96-106. [CrossRef] [PubMed]

87. De Oliveira, T.; Abiatari, I.; Raulefs, S.; Sauliunaite, D.; Erkan, M.; Kong, B.; Friess, H.; Michalski, C.W.; Kleeff, J. Syndecan-2 promotes perineural invasion and cooperates with K-ras to induce an invasive pancreatic cancer cell phenotype. Mol. Cancer 2012, 11, 19. [CrossRef] [PubMed]

88. Swanson, B.J.; McDermott, K.M.; Singh, P.K.; Eggers, J.P.; Crocker, P.R.; Hollingsworth, M.A. MUC1 Is a Counter-Receptor for Myelin-Associated Glycoprotein (Siglec-4a) and Their Interaction Contributes to Adhesion in Pancreatic Cancer Perineural Invasion. Cancer Res. 2007, 67, 10222-10229. [CrossRef]

89. Bressy, C.; Lac, S.; Nigri, J.E.; Leca, J.; Roques, J.; Lavaut, M.N.; Secq, V.; Guillaumond, F.; Bui, T.T.; Pietrasz, D.; et al. LIF drives neural remodeling in pancreatic cancer and offers a new candidate biomarker. Cancer Res. 2018, 78, 909-921. [CrossRef]

90. Deborde, S.; Wong, R.J. How Schwann cells facilitate cancer progression in nerves. Cell. Mol. Life Sci. 2017, 74, 4405-4420. [CrossRef]

91. Demir, I.E.; Boldis, A.; Pfitzinger, P.L.; Teller, S.; Brunner, E.; Klose, N.; Kehl, T.; Maak, M.; Lesina, M.; Laschinger, M.; et al. Investigation of schwann cells at neoplastic cell sites before the onset of cancer invasion. J. Natl. Cancer Inst. 2014, 106, dju184. [CrossRef] [PubMed]

92. Deborde, S.; Omelchenko, T.; Lyubchik, A.; Zhou, Y.; He, S.; McNamara, W.F.; Chernichenko, N.; Lee, S.Y.; Barajas, F.; Chen, C.H.; et al. Schwann cells induce cancer cell dispersion and invasion. J. Clin. Investig. 2016, 126, 1538-1554. [CrossRef] [PubMed] 
93. Kalluri, R. The biology and function of fibroblasts in cancer. Nat. Rev. Cancer 2016, 16, 582-598. [CrossRef] [PubMed]

94. Von Ahrens, D.; Bhagat, T.D.; Nagrath, D.; Maitra, A.; Verma, A. The role of stromal cancer-associated fibroblasts in pancreatic cancer. J. Hematol. Oncol. 2017, 10, 76. [CrossRef] [PubMed]

95. Qu, C.; Wang, Q.; Meng, Z.; Wang, P. Cancer-Associated Fibroblasts in Pancreatic Cancer: Should They Be Deleted or Reeducated? Integr. Cancer Ther. 2018, 17, 1016-1019. [CrossRef] [PubMed]

96. Bhowmick, N.A.; Neilson, E.G.; Moses, H.L. Stromal fibroblasts in cancer initiation and progression. Nature 2004, 432, 332-337. [CrossRef] [PubMed]

97. Öhlund, D.; Handly-Santana, A.; Biffi, G.; Elyada, E.; Almeida, A.S.; Ponz-Sarvise, M.; Corbo, V.; Oni, T.E.; Hearn, S.A.; Lee, E.J.; et al. Distinct populations of inflammatory fibroblasts and myofibroblasts in pancreatic cancer. J. Exp. Med. 2017, 214, 579-596. [CrossRef]

98. Dun, X.-P.; Carr, L.; Woodley, P.K.; Barry, R.W.; Drake, L.K.; Mindos, T.; Roberts, S.L.; Lloyd, A.C.; Parkinson, D.B. Macrophage-Derived Slit3 Controls Cell Migration and Axon Pathfinding in the Peripheral Nerve Bridge. Cell Rep. 2019, 26, 1458-1472. [CrossRef]

99. Nicola, N.A.; Babon, J.J. Leukemia inhibitory factor (LIF). Cytokine Growth Factor Rev. 2015, 26, 533-544. [CrossRef]

100. Albrengues, J.; Bourget, I.; Pons, C.; Butet, V.; Hofman, P.; Tartare-Deckert, S.; Feral, C.C.; Meneguzzi, G.; Gaggioli, C. LIF Mediates Proinvasive Activation of Stromal Fibroblasts in Cancer. Cell Rep. 2014, 7, 1664-1678. [CrossRef]

101. Vonlaufen, A.; Joshi, S.; Qu, C.; Phillips, P.A.; Xu, Z.; Parker, N.R.; Toi, C.S.; Pirola, R.C.; Wilson, J.S.; Goldstein, D.; et al. Pancreatic Stellate Cells: Partners in Crime with Pancreatic Cancer Cells. Cancer Res. 2008, 68, 2085-2093. [CrossRef] [PubMed]

102. Thomas, D.; Radhakrishnan, P. Tumor-stromal crosstalk in pancreatic cancer and tissue fibrosis. Mol. Cancer 2019, 18, 14. [CrossRef] [PubMed]

103. Moir, J.A.G.; Mann, J.; White, S.A. The role of pancreatic stellate cells in pancreatic cancer. Surg. Oncol. 2015, 24, 232-238. [CrossRef] [PubMed]

104. Haas, S.L.; Haas, S.L.; Fitzner, B.; Haas, S.L.; Fitzner, B.; Jaster, R.; Wiercinska, E.; Gaitantzi, H.; Jesenowski, R.; Löhr, J.-M.; et al. Transforming growth factor- $\beta$ induces nerve growth factor expression in pancreatic stellate cells by activation of the ALK-5 pathway. Growth Factors 2009, 27, 289-299. [CrossRef] [PubMed]

105. Li, X.; Wang, Z.; Ma, Q.; Xu, Q.; Liu, H.; Duan, W.; Lei, J.; Ma, J.; Wang, X.; Lv, S.; et al. Sonic Hedgehog Paracrine Signaling Activates Stromal Cells to Promote Perineural Invasion in Pancreatic Cancer. Clin. Cancer Res. 2014, 20, 4326-4338. [CrossRef] [PubMed]

106. Pollard, J.W. Tumour-educated macrophages promote tumour progression and metastasis. Nat. Rev. Cancer 2004, 4, 71-78. [CrossRef] [PubMed]

107. Noy, R.; Pollard, J.W. Tumor-Associated Macrophages: From Mechanisms to Therapy. Immunity 2014, 41, 49-61. [CrossRef]

108. Demir, I.E.; Schorn, S.; Schremmer-Danninger, E.; Wang, K.; Kehl, T.; Giese, N.A.; Algül, H.; Friess, H.; Ceyhan, G.O. Perineural Mast Cells Are Specifically Enriched in Pancreatic Neuritis and Neuropathic Pain in Pancreatic Cancer and Chronic Pancreatitis. PLoS ONE 2013, 8, e60529. [CrossRef]

109. Qian, B.-Z.; Pollard, J.W. Macrophage Diversity Enhances Tumor Progression and Metastasis. Cell 2010, 141, 39-51. [CrossRef]

110. Clark, C.E.; Hingorani, S.R.; Mick, R.; Combs, C.; Tuveson, D.A.; Vonderheide, R.H. Dynamics of the Immune Reaction to Pancreatic Cancer from Inception to Invasion. Cancer Res. 2007, 67, 9518-9527. [CrossRef]

111. Zeng, L.; Guo, Y.; Liang, J.; Chen, S.; Peng, P.; Zhang, Q.; Su, H.; Chen, Y.; Huang, K. Perineural Invasion and TAMs in Pancreatic Ductal Adenocarcinomas: Review of the Original Pathology Reports Using Immunohistochemical Enhancement and Relationships with Clinicopathological Features. J. Cancer 2014, 5, 754-760. [CrossRef] [PubMed]

112. Saloman, J.L.; Singhi, A.D.; Hartman, D.J.; Normolle, D.P.; Albers, K.M.; Davis, B.M. Systemic Depletion of Nerve Growth Factor Inhibits Disease Progression in a Genetically Engineered Model of Pancreatic Ductal Adenocarcinoma. Pancreas 2018, 47, 856-863. [CrossRef] [PubMed]

113. Schwartz, E.S.; Christianson, J.A.; Chen, X.; La, J.; Davis, B.M.; Albers, K.M.; Gebhart, G.F. Synergistic Role of TRPV1 and TRPA1 in Pancreatic Pain and Inflammation. Gastroenterology 2011, 140, 1283-1291. [CrossRef] [PubMed] 
114. Schwartz, E.S.; La, J.-H.; Scheff, N.N.; Davis, B.M.; Albers, K.M.; Gebhart, G.F. TRPV1 and TRPA1 antagonists prevent the transition of acute to chronic inflammation and pain in chronic pancreatitis. J. Neurosci. 2013, 33, 5603-5611. [CrossRef] [PubMed]

115. Jessen, K.R.; Mirsky, R. The origin and development of glial cells in peripheral nerves. Nat. Rev. Neurosci. 2005, 6, 671-682. [CrossRef] [PubMed]

116. Van Steenwinckel, J.; Reaux-Le Goazigo, A.; Pommier, B.; Mauborgne, A.; Dansereau, M.-A.; Kitabgi, P.; Sarret, P.; Pohl, M.; Melik Parsadaniantz, S. CCL2 Released from Neuronal Synaptic Vesicles in the Spinal Cord Is a Major Mediator of Local Inflammation and Pain after Peripheral Nerve Injury. J. Neurosci. 2011, 31, 5865-5875. [CrossRef] [PubMed]

117. Bakst, R.L.; Xiong, H.; Chen, C.-H.; Deborde, S.; Lyubchik, A.; Zhou, Y.; He, S.; McNamara, W.; Lee, S.-Y.; Olson, O.C.; et al. Inflammatory Monocytes Promote Perineural Invasion via CCL2-Mediated Recruitment and Cathepsin B Expression. Cancer Res. 2017, 77, 6400-6414. [CrossRef]

118. Nywening, T.M.; Wang-Gillam, A.; Sanford, D.E.; Belt, B.A.; Panni, R.Z.; Cusworth, B.M.; Toriola, A.T.; Nieman, R.K.; Worley, L.A.; Yano, M.; et al. Targeting tumour-associated macrophages with CCR2 inhibition in combination with FOLFIRINOX in patients with borderline resectable and locally advanced pancreatic cancer: A single-centre, open-label, dose-finding, non-randomised, phase $1 \mathrm{~b}$ trial. Lancet Oncol. 2016, 17, 651-662. [CrossRef]

119. Monk, K.R.; Feltri, M.L.; Taveggia, C. New insights on schwann cell development. Glia 2015, 63, $1376-1393$. [CrossRef]

120. Pellegatta, M.; Taveggia, C. The Complex Work of Proteases and Secretases in Wallerian Degeneration: Beyond Neuregulin-1. Front. Cell. Neurosci. 2019, 13, 93. [CrossRef]

121. Celesti, G.; Di Caro, G.; Bianchi, P.; Grizzi, F.; Marchesi, F.; Basso, G.; Rahal, D.; Delconte, G.; Catalano, M.; Cappello, P.; et al. Early expression of the fractalkine receptor CX3CR1 in pancreatic carcinogenesis. Br. J. Cancer 2013, 109, 2424-2433. [CrossRef] [PubMed]

122. Marchesi, F.; Locatelli, M.; Solinas, G.; Erreni, M.; Allavena, P.; Mantovani, A. Role of CX3CR1/CX3CL1 axis in primary and secondary involvement of the nervous system by cancer. J. Neuroimmunol. 2010, 224, 39-44. [CrossRef] [PubMed]

123. Stout, M.C.; Narayan, S.; Pillet, E.S.; Salvino, J.M.; Campbell, P.M. Inhibition of CX3CR1 reduces cell motility and viability in pancreatic adenocarcinoma epithelial cells. Biochem. Biophys. Res. Commun. 2018, 495, 2264-2269. [CrossRef] [PubMed]

124. Miknyoczki, S.J.; Lang, D.; Huang, L.; Klein-Szanto, A.J.; Dionne, C.A.; Ruggeri, B.A. Neurotrophins and Trk receptors in human pancreatic ductal adenocarcinoma: Expression patterns and effects on In Vitro invasive behavior. Int. J. Cancer 1999, 81, 417-427. [CrossRef]

125. Miknyoczki, S.J.; Wan, W.; Chang, H.; Dobrzanski, P.; Ruggeri, B.A.; Dionne, C.A.; Buchkovich, K. The neurotrophin-trk receptor axes are critical for the growth and progression of human prostatic carcinoma and pancreatic ductal adenocarcinoma xenografts in nude mice. Clin. Cancer Res. 2002, 8, 1924-1931. [PubMed]

126. Zhu, Z.; Kleeff, J.; Kayed, H.; Wang, L.; Korc, M.; Büchler, M.W.; Friess, H. Nerve growth factor and enhancement of proliferation, invasion and tumorigenicity of pancreatic cancer cells. Mol. Carcinog. 2002, 35, 138-147. [CrossRef] [PubMed]

127. Glenn, T.D.; Talbot, W.S. Signals regulating myelination in peripheral nerves and the Schwann cell response to injury. Curr. Opin. Neurobiol. 2013, 23, 1041-1048. [CrossRef] [PubMed]

128. Wang, K.; Demir, I.E.; D’Haese, J.G.; Tieftrunk, E.; Kujundzic, K.; Schorn, S.; Xing, B.; Kehl, T.; Friess, H.; Ceyhan, G.O. The neurotrophic factor neurturin contributes toward an aggressive cancer cell phenotype, neuropathic pain and neuronal plasticity in pancreatic cancer. Carcinogenesis 2014, 35, 103-113. [CrossRef]

129. Zhu, Z.; Friess, H.; diMola, F.F.; Zimmermann, A.; Graber, H.U.; Korc, M.; Büchler, M.W. Nerve Growth Factor Expression Correlates with Perineural Invasion and Pain in Human Pancreatic Cancer. J. Clin. Oncol. 1999, 17, 2419. [CrossRef]

130. Zhu, Z.W.; Friess, H.; Wang, L.; Bogardus, T.; Korc, M.; Kleef, J.; Büchler, M.W. Nerve growth factor exerts differential effects on the growth of human pancreatic cancer cells. Clin. Cancer Res. 2001, 7, 105-112.

131. Ma, J.; Jiang, Y.; Jiang, Y.; Sun, Y.; Zhao, X. Expression of nerve growth factor and tyrosine kinase receptor A and correlation with perineural invasion in pancreatic cancer. J. Gastroenterol. Hepatol. 2008, 23, 1852-1859. [CrossRef] [PubMed] 
132. Schneider, M.B.; Standop, J.; Ulrich, A.; Wittel, U.; Friess, H.; Andrén-Sandberg, Å.; Pour, P.M. Expression of Nerve Growth Factors in Pancreatic Neural Tissue and Pancreatic Cancer. J. Histochem. Cytochem. 2001, 49, 1205-1210. [CrossRef] [PubMed]

133. Lei, Y.; Tang, L.; Xie, Y.; Xianyu, Y.; Zhang, L.; Wang, P.; Hamada, Y.; Jiang, K.; Zheng, W.; Jiang, X. Gold nanoclusters-assisted delivery of NGF siRNA for effective treatment of pancreatic cancer. Nat. Commun. 2017, 8, 15130. [CrossRef] [PubMed]

134. Wang, W.; Zhao, H.; Zhang, S.; Kang, E.; Chen, Y.; Ni, C.; Zhang, S.; Zhu, M. Patterns of expression and function of the p75NGFR protein in pancreatic cancer cells and tumours. Eur. J. Surg. Oncol. 2009, 35, 826-832. [CrossRef] [PubMed]

135. Bapat, A.A.; Munoz, R.M.; Von Hoff, D.D.; Han, H. Blocking Nerve Growth Factor Signaling Reduces the Neural Invasion Potential of Pancreatic Cancer Cells. PLoS ONE 2016, 11, e0165586. [CrossRef] [PubMed]

136. Ceyhan, G.O.; Demir, I.E.; Altintas, B.; Rauch, U.; Thiel, G.; Müller, M.W.; Giese, N.A.; Friess, H.; Schäfer, K.H. Neural invasion in pancreatic cancer: A mutual tropism between neurons and cancer cells. Biochem. Biophys. Res. Commun. 2008, 374, 442-447. [CrossRef] [PubMed]

137. Sclabas, G.M.; Fujioka, S.; Schmidt, C.; Li, Z.; Frederick, W.A.I.; Yang, W.; Yokoi, K.; Evans, D.B.; Abbruzzese, J.L.; Hess, K.R.; et al. Overexpression of tropomysin-related kinase B in metastatic human pancreatic cancer cells. Clin. Cancer Res. 2005, 11, 440-449.

138. Sakamoto, Y.; Kitajima, Y.; Edakuni, G.; Sasatomi, E.; Mori, M.; Kitahara, K.; Miyazaki, K. Expression of Trk tyrosine kinase receptor is a biologic marker for cell proliferation and perineural invasion of human pancreatic ductal adenocarcinoma. Oncol. Rep. 2001, 8, 477-484. [CrossRef]

139. Johnson, M.D.; Stone, B.; Thibodeau, B.J.; Baschnagel, A.M.; Galoforo, S.; Fortier, L.E.; Ketelsen, B.; Ahmed, S.; Kelley, Z.; Hana, A.; et al. The significance of Trk receptors in pancreatic cancer. Tumor Biol. 2017, 39, 101042831769225. [CrossRef]

140. Song, L.; Liu, D.; Guan, H.; Zhang, Y.; Kang, H.; Yan, W.; Zhang, S.; Dai, Z.; Zhao, X. MiR-429 suppresses neurotrophin-3 to alleviate perineural invasion of pancreatic cancer. Biochem. Biophys. Res. Commun. 2018, $505,1077-1083$

141. Ketterer, K.; Rao, S.; Friess, H.; Weiss, J.; Büchler, M.W.; Korc, M. Reverse transcription-PCR analysis of laser-captured cells points to potential paracrine and autocrine actions of neurotrophins in pancreatic cancer. Clin. Cancer Res. 2003, 9, 5127-5136. [PubMed]

142. He, S.; Chen, C.-H.; Chernichenko, N.; He, S.; Bakst, R.L.; Barajas, F.; Deborde, S.; Allen, P.J.; Vakiani, E.; Yu, Z.; et al. GFR $\alpha 1$ released by nerves enhances cancer cell perineural invasion through GDNF-RET signaling. Proc. Natl. Acad. Sci. USA 2014, 111, E2008-E2017. [CrossRef] [PubMed]

143. Sawai, H.; Okada, Y.; Kazanjian, K.; Kim, J.; Hasan, S.; Hines, O.J.; Reber, H.A.; Hoon, D.S.B.; Eibl, G. The G691S RET Polymorphism Increases Glial Cell Line-Derived Neurotrophic Factor-Induced Pancreatic Cancer Cell Invasion by Amplifying Mitogen-Activated Protein Kinase Signaling. Cancer Res. 2005, 65, 11536-11544. [CrossRef] [PubMed]

144. Mulligan, L.M. GDNF and the RET Receptor in Cancer: New Insights and Therapeutic Potential. Front. Physiol. 2018, 9, 1873. [CrossRef] [PubMed]

145. Demir, I.E.; Wang, K.; Tieftrunk, E.; Giese, N.A.; Xing, B.; Friess, H.; Kehl, T.; Ceyhan, G.O. Neuronal plasticity in chronic pancreatitis is mediated via the neurturin/GFR 2 axis. AJP Gastrointest. Liver Physiol. 2012, 303, G1017-G1028. [CrossRef] [PubMed]

146. Ceyhan, G.O.; Bergmann, F.; Kadihasanoglu, M.; Erkan, M.; Park, W.; Hinz, U.; Giese, T.; Muller, M.W.; Buchler, M.W.; Giese, N.A.; et al. The neurotrophic factor artemin influences the extent of neural damage and growth in chronic pancreatitis. Gut 2007, 56, 534-544. [CrossRef]

147. Ceyhan, G.O.; Schäfer, K.-H.; Kerscher, A.G.; Rauch, U.; Demir, I.E.; Kadihasanoglu, M.; Böhm, C.; Müller, M.W.; Büchler, M.W.; Giese, N.A.; et al. Nerve growth factor and artemin are paracrine mediators of pancreatic neuropathy in pancreatic adenocarcinoma. Ann. Surg. 2010, 251, 923-931. [CrossRef]

148. Wang, J.; Wang, H.; Cai, J.; Du, S.; Xin, B.; Wei, W.; Zhang, T.; Shen, X. Artemin regulates CXCR4 expression to induce migration and invasion in pancreatic cancer cells through activation of NF-KB signaling. Exp. Cell Res. 2018, 365, 12-23. [CrossRef]

149. Schreiber, S.C.; Giehl, K.; Kastilan, C.; Hasel, C.; Mühlenhoff, M.; Adler, G.; Wedlich, D.; Menke, A. Polysialylated NCAM Represses E-Cadherin-Mediated Cell-Cell Adhesion in Pancreatic Tumor Cells. Gastroenterology 2008, 134, 1555-1566. [CrossRef] 
150. Kameda, K.; Shimada, H.; Ishikawa, T.; Takimoto, A.; Momiyama, N.; Hasegawa, S.; Misuta, K.; Nakano, A.; Nagashima, Y.; Ichikawa, Y. Expression of highly polysialylated neural cell adhesion molecule in pancreatic cancer neural invasive lesion. Cancer Lett. 1999, 137, 201-207. [CrossRef]

151. Tezel, E.; Kawase, Y.; Takeda, S.; Oshima, K.; Nakao, A. Expression of neural cell adhesion molecule in pancreatic cancer. Pancreas 2001, 22, 122-125. [CrossRef] [PubMed]

152. Bergmann, F.; Wandschneider, F.; Sipos, B.; Moldenhauer, G.; Schniewind, B.; Welsch, T.; Schirrmacher, P.; Klöppel, G.; Altevogt, P.; Schäfer, H.; et al. Elevated L1CAM expression in precursor lesions and primary and metastastic tissues of pancreatic ductal adenocarcinoma. Oncol. Rep. 2010, 24, 909-915. [PubMed]

153. Ben, Q.; An, W.; Fei, J.; Xu, M.; Li, G.; Li, Z.; Yuan, Y. Downregulation of L1CAM inhibits proliferation, invasion and arrests cell cycle progression in pancreatic cancer cells in vitro. Exp. Ther. Med. 2014, 7, 785-790. [CrossRef] [PubMed]

154. Hua, T.; Liu, S.; Xin, X.; Jin, Z.; Liu, Q.; Chi, S.; Wang, X.; Wang, H. Prognostic significance of L1 cell adhesion molecule in cancer patients: A systematic review and meta-analysis. Oncotarget 2016, 7, 85196-85207. [CrossRef] [PubMed]

155. Lund, K.; Dembinski, J.L.; Solberg, N.; Urbanucci, A.; Mills, I.G.; Krauss, S. Slug-Dependent Upregulation of L1CAM Is Responsible for the Increased Invasion Potential of Pancreatic Cancer Cells following Long-Term 5-FU Treatment. PLoS ONE 2015, 10, e0123684. [CrossRef] [PubMed]

156. Kaifi, J.T.; Strelow, A.; Schurr, P.G.; Reichelt, U.; Yekebas, E.F.; Wachowiak, R.; Quaas, A.; Strate, T.; Schaefer, H.; Sauter, G.; et al. L1 (CD171) is highly expressed in gastrointestinal stromal tumors. Mod. Pathol. 2006, 19, 399-406. [CrossRef] [PubMed]

157. Lo, S.-T.; Pantazopouos, P.; Medarova, Z.; Moore, A. Presentation of underglycosylated mucin 1 in pancreatic adenocarcinoma (PDAC) at early stages. Am. J. Cancer Res. 2016, 6, 1986-1995.

158. Wang, Y.; Teng, H.-L.; Huang, Z.-H. Repulsive migration of schwann cells induced by slit-2 through $\mathrm{Ca}^{2+}$-dependent RhoA-Myosin signaling. Glia 2013, 61, 710-723. [CrossRef]

159. Lüttges, J.; Zamboni, G.; Longnecker, D.; Klöppel, G. The immunohistochemical mucin expression pattern distinguishes different types of intraductal papillary mucinous neoplasms of the pancreas and determines their relationship to mucinous noncystic carcinoma and ductal adenocarcinoma. Am. J. Surg. Pathol. 2001, 25, 942-948. [CrossRef]

160. Remmers, N.; Anderson, J.M.; Linde, E.M.; DiMaio, D.J.; Lazenby, A.J.; Wandall, H.H.; Mandel, U.; Clausen, H.; Yu, F.; Hollingsworth, M.A. Aberrant Expression of Mucin Core Proteins and O-Linked Glycans Associated with Progression of Pancreatic Cancer. Clin. Cancer Res. 2013, 19, 1981-1993. [CrossRef]

161. Hinoda, Y.; Ikematsu, Y.; Horinochi, M.; Sato, S.; Yamamoto, K.; Nakano, T.; Fukui, M.; Suehiro, Y.; Hamanaka, Y.; Nishikawa, Y.; et al. Increased expression of MUC1 in advanced pancreatic cancer. J. Gastroenterol. 2003, 38, 1162-1166. [CrossRef] [PubMed]

162. Levi, E.; Klimstra, D.S.; Andea, A.; Basturk, O.; Adsay, N.V. MUC1 and MUC2 in pancreatic neoplasia. J. Clin. Pathol. 2004, 57, 456-462. [CrossRef] [PubMed]

163. Okada, Y.; Eibl, G.; Duffy, J.P.; Reber, H.A.; Hines, O.J. Glial cell-derived neurotrophic factor upregulates the expression and activation of matrix metalloproteinase-9 in human pancreatic cancer. Surgery 2003, 134, 293-299. [CrossRef] [PubMed]

164. Okada, Y.; Eibl, G.; Guha, S.; Duffy, J.P.; Reber, H.A.; Hines, O.J. Nerve growth factor stimulates MMP-2 expression and activity and increases invasion by human pancreatic cancer cells. Clin. Exp. Metastasis 2004, 21, 285-292. [CrossRef] [PubMed]

165. Zhai, L.-L.; Wu, Y.; Huang, D.-W.; Tang, Z.-G. Increased matrix metalloproteinase-2 expression and reduced tissue factor pathway inhibitor-2 expression correlate with angiogenesis and early postoperative recurrence of pancreatic carcinoma. Am. J. Transl. Res. 2015, 7, 2412-2422. [PubMed]

166. Blondy, S.; Christou, N.; David, V.; Verdier, M.; Jauberteau, M.-O.; Mathonnet, M.; Perraud, A. Neurotrophins and their involvement in digestive cancers. Cell Death Dis. 2019, 10, 123. [CrossRef] [PubMed]

167. Bothwell, M. Recent advances in understanding neurotrophin signaling. F1000Research 2016, 5, 1885. [CrossRef]

168. Sariola, H. The neurotrophic factors in non-neuronal tissues. Cell. Mol. Life Sci. 2001, 58, 1061-1066. [CrossRef]

169. Reichardt, L.F. Neurotrophin-regulated signalling pathways. Philos. Trans. R. Soc. B Biol. Sci. 2006, 361, 1545-1564. [CrossRef]

170. Skaper, S.D. Neurotrophic Factors: An Overview; Humana Press: New York, NY, USA, 2018; pp. 1-17. 
171. Nykjaer, A.; Lee, R.; Teng, K.K.; Jansen, P.; Madsen, P.; Nielsen, M.S.; Jacobsen, C.; Kliemannel, M.; Schwarz, E.; Willnow, T.E.; et al. Sortilin is essential for proNGF-induced neuronal cell death. Nature 2004, 427, $843-848$. [CrossRef]

172. Levi-Montalcini, R. The nerve growth factor: Thirty-five years later. Biosci. Rep. 1987, 7, 681-699. [CrossRef] [PubMed]

173. Barbacid, M. Structural and functional properties of the TRK family of neurotrophin receptors. Ann. N. Y. Acad. Sci. 1995, 766, 442-458. [CrossRef] [PubMed]

174. Barde, Y.-A. The nerve growth factor family. Prog. Growth Factor Res. 1990, 2, 237-248. [CrossRef]

175. Skaper, S.D. Nerve growth factor: A neuroimmune crosstalk mediator for all seasons. Immunology 2017, 151, 1-15. [CrossRef] [PubMed]

176. Bernd, P. The role of neurotrophins during early development. Gene Expr. 2008, 14, 241-250. [CrossRef] [PubMed]

177. Liu, H.; Ma, Q.; Xu, Q.; Lei, J.; Li, X.; Wang, Z.; Wu, E. Therapeutic potential of perineural invasion, hypoxia and desmoplasia in pancreatic cancer. Curr. Pharm. Des. 2012, 18, 2395-2403. [CrossRef] [PubMed]

178. Zeng, Q.; Cheng, Y.; Zhu, Q.; Yu, Z.; Wu, X.; Huang, K.; Zhou, M.; Han, S.; Zhang, Q. The relationship between overexpression of glial cell-derived neurotrophic factor and its RET receptor with progression and prognosis of human pancreatic cancer. J. Int. Med. Res. 2008, 36, 656-664. [CrossRef]

179. Airaksinen, M.S.; Saarma, M. The GDNF family: Signalling, biological functions and therapeutic value. Nat. Rev. Neurosci. 2002, 3, 383-394. [CrossRef]

180. Okada, Y.; Takeyama, H.; Sato, M.; Morikawa, M.; Sobue, K.; Asai, K.; Tada, T.; Kato, T.; Manabe, T. Experimental implication of celiac ganglionotropic invasion of pancreatic-cancer cells bearing c-ret proto-oncogene with reference to glial-cell-line-derived neurotrophic factor (GDNF). Int. J. Cancer 1999, 81, 67-73. [CrossRef]

181. Ito, Y.; Okada, Y.; Sato, M.; Sawai, H.; Funahashi, H.; Murase, T.; Hayakawa, T.; Manabe, T. Expression of glial cell line-derived neurotrophic factor family members and their receptors in pancreatic cancers. Surgery 2005, 138, 788-794. [CrossRef]

182. Paratcha, G.; Ledda, F.; Baars, L.; Coulpier, M.; Besset, V.; Anders, J.; Scott, R.; Ibáñez, C.F. Released GFRalpha1 potentiates downstream signaling, neuronal survival and differentiation via a novel mechanism of recruitment of c-Ret to lipid rafts. Neuron 2001, 29, 171-184. [CrossRef]

183. Rossi, J.; Santamä Ki, P.; Airaksinen, M.S.; Herzig, K.-H. Parasympathetic Innervation and Function of Endocrine Pancreas Requires the Glial Cell Line-Derived Factor Family Receptor 2 (GFR2). Diabetes 2005, 54, 1324-1330. [CrossRef] [PubMed]

184. Gao, L.; Bo, H.; Wang, Y.; Zhang, J.; Zhu, M. Neurotrophic Factor Artemin Promotes Invasiveness and Neurotrophic Function of Pancreatic Adenocarcinoma In Vivo and In Vitro. Pancreas 2015, 44, 134-143. [CrossRef] [PubMed]

185. Balkwill, F. Cancer and the chemokine network. Nat. Rev. Cancer 2004, 4, 540-550. [CrossRef]

186. Hedin, K.E. Chemokines: New, Key Players in the Pathobiology of Pancreatic Cancer. Int. J. Gastrointest. Cancer 2002, 31, 23-30. [CrossRef]

187. Marchesi, F.; Piemonti, L.; Allavena, P. Molecular mechanisms of perineural invasion, a forgotten pathway of dissemination and metastasis. Cytokine Growth Factor Rev. 2010, 21, 77-82. [CrossRef] [PubMed]

188. Verge, G.M.; Milligan, E.D.; Maier, S.F.; Watkins, L.R.; Naeve, G.S.; Foster, A.C. Fractalkine (CX3CL1) and fractalkine receptor (CX3CR1) distribution in spinal cord and dorsal root ganglia under basal and neuropathic pain conditions. Eur. J. Neurosci. 2004, 20, 1150-1160. [CrossRef]

189. Imai, T.; Hieshima, K.; Haskell, C.; Baba, M.; Nagira, M.; Nishimura, M.; Kakizaki, M.; Takagi, S.; Nomiyama, H.; Schall, T.J.; et al. Identification and molecular characterization of fractalkine receptor CX3CR1, which mediates both leukocyte migration and adhesion. Cell 1997, 91, 521-530. [CrossRef]

190. Lauro, C.; Catalano, M.; Trettel, F.; Mainiero, F.; Ciotti, M.T.; Eusebi, F.; Limatola, C. The Chemokine CX3CL1 Reduces Migration and Increases Adhesion of Neurons with Mechanisms Dependent on the 1 Integrin Subunit. J. Immunol. 2006, 177, 7599-7606. [CrossRef]

191. Harrison, J.K.; Jiang, Y.; Chen, S.; Xia, Y.; Maciejewski, D.; McNamara, R.K.; Streit, W.J.; Salafranca, M.N.; Adhikari, S.; Thompson, D.A.; et al. Role for neuronally derived fractalkine in mediating interactions between neurons and CX3CR1-expressing microglia. Proc. Natl. Acad. Sci. USA 1998, 95, 10896-10901. [CrossRef] 
192. Cardona, A.E.; Pioro, E.P.; Sasse, M.E.; Kostenko, V.; Cardona, S.M.; Dijkstra, I.M.; Huang, D.; Kidd, G.; Dombrowski, S.; Dutta, R.; et al. Control of microglial neurotoxicity by the fractalkine receptor. Nat. Neurosci. 2006, 9, 917-924. [CrossRef] [PubMed]

193. Dickson, B.J.; Gilestro, G.F. Regulation of Commissural Axon Pathfinding by Slit and its Robo Receptors. Annu. Rev. Cell Dev. Biol. 2006, 22, 651-675. [CrossRef] [PubMed]

194. Ma, L.; Tessier-Lavigne, M. Dual Branch-Promoting and Branch-Repelling Actions of Slit/Robo Signaling on Peripheral and Central Branches of Developing Sensory Axons. J. Neurosci. 2007, 27, 6843-6851. [CrossRef] [PubMed]

195. Li, H.S.; Chen, J.H.; Wu, W.; Fagaly, T.; Zhou, L.; Yuan, W.; Dupuis, S.; Jiang, Z.H.; Nash, W.; Gick, C.; et al. Vertebrate slit, a secreted ligand for the transmembrane protein roundabout, is a repellent for olfactory bulb axons. Cell 1999, 96, 807-818. [CrossRef]

196. De Bellard, M.E.; Rao, Y.; Bronner-Fraser, M. Dual function of Slit2 in repulsion and enhanced migration of trunk but not vagal, neural crest cells. J. Cell Biol. 2003, 162, 269-279. [CrossRef] [PubMed]

197. Giovannone, D.; Reyes, M.; Reyes, R.; Correa, L.; Martinez, D.; Ra, H.; Gomez, G.; Kaiser, J.; Ma, L.; Stein, M.-P.; et al. Slits affect the timely migration of neural crest cells via Robo receptor. Dev. Dyn. 2012, 241, 1274-1288. [CrossRef]

198. Escot, S.; Willnow, D.; Naumann, H.; Di Francescantonio, S.; Spagnoli, F.M. Robo signalling controls pancreatic progenitor identity by regulating Tead transcription factors. Nat. Commun. 2018, 9, 5082. [CrossRef]

199. Hirohashi, S.; Kanai, Y. Cell adhesion system and human cancer morphogenesis. Cancer Sci. 2003, 94, 575-581. [CrossRef]

200. Cavallaro, U.; Dejana, E. Adhesion molecule signalling: Not always a sticky business. Nat. Rev. Mol. Cell Biol. 2011, 12, 189-197. [CrossRef]

201. Neuberger, T.J.; Cornbrooks, C.J. Transient modulation of Schwann cell antigens after peripheral nerve transection and subsequent regeneration. J. Neurocytol. 1989, 18, 695-710. [CrossRef]

202. Maness, P.F.; Schachner, M. Neural recognition molecules of the immunoglobulin superfamily: Signaling transducers of axon guidance and neuronal migration. Nat. Neurosci. 2007, 10, 19-26. [CrossRef] [PubMed]

203. Ditlevsen, D.K.; Povlsen, G.K.; Berezin, V.; Bock, E. NCAM-induced intracellular signaling revisited. J. Neurosci. Res. 2008, 86, 727-743. [CrossRef] [PubMed]

204. Saffell, J.L.; Walsh, F.S.; Doherty, P. Direct activation of second messenger pathways mimics cell adhesion molecule-dependent neurite outgrowth. J. Cell Biol. 1992, 118, 663-670. [CrossRef] [PubMed]

205. Lindner, J.; Rathjen, F.G.; Schachner, M. L1 mono- and polyclonal antibodies modify cell migration in early postnatal mouse cerebellum. Nature 1983, 305, 427-430. [CrossRef] [PubMed]

206. Altevogt, P.; Doberstein, K.; Fogel, M. L1CAM in human cancer. Int. J. Cancer 2016, 138, 1565-1576. [CrossRef] [PubMed]

207. Na'ara, S.; Amit, M.; Gil, Z. L1CAM induces perineural invasion of pancreas cancer cells by upregulation of metalloproteinase expression. Oncogene 2018, 38, 596-608. [CrossRef] [PubMed]

208. Hollingsworth, M.A.; Swanson, B.J. Mucins in cancer: Protection and control of the cell surface. Nat. Rev. Cancer 2004, 4, 45-60. [CrossRef] [PubMed]

209. Suh, H.; Pillai, K.; Morris, D.L. Mucins in pancreatic cancer: Biological role, implications in carcinogenesis and applications in diagnosis and therapy. Am. J. Cancer Res. 2017, 7, 1372-1383.

210. Burdick, M.D.; Harris, A.; Reid, C.J.; Iwamura, T.; Hollingsworth, M.A. Oligosaccharides Expressed on MUC1 Produced by Pancreatic and Colon Tumor Cell Lines. J. Biol. Chem. 1997, 272, 24198-24202. [CrossRef]

211. Beum, P.V.; Singh, J.; Burdick, M.; Hollingsworth, M.A.; Cheng, P.-W. Expression of Core 2 $\beta-1,6-N$-Acetylglucosaminyltransferase in a Human Pancreatic Cancer Cell Line Results in Altered Expression of MUC1 Tumor-associated Epitopes. J. Biol. Chem. 1999, 274, 24641-24648. [CrossRef]

212. Ren, J.; Agata, N.; Chen, D.; Li, Y.; Yu, W.; Huang, L.; Raina, D.; Chen, W.; Kharbanda, S.; Kufe, D. Human MUC1 carcinoma-associated protein confers resistance to genotoxic anticancer agents. Cancer Cell 2004, 5, 163-175. [CrossRef]

213. Nath, S.; Daneshvar, K.; Roy, L.D.; Grover, P.; Kidiyoor, A.; Mosley, L.; Sahraei, M.; Mukherjee, P. MUC1 induces drug resistance in pancreatic cancer cells via upregulation of multidrug resistance genes. Oncogenesis 2013, 2, e51. [CrossRef] [PubMed] 
214. Knapinska, A.M.; Estrada, C.A.; Fields, G.B.; Fields, G.B. The Roles of Matrix Metalloproteinases in Pancreatic Cancer. In Progress in Molecular Biology and Translational Science; 2017; Volume 148, pp. 339-354. ISBN 9780128127766.

215. Jakubowska, K.; Pryczynicz, A.; Januszewska, J.; Sidorkiewicz, I.; Kemona, A.; Niewiński, A.; Lewczuk, Ł.; Kędra, B.; Guzińska-Ustymowicz, K. Expressions of Matrix Metalloproteinases 2, 7 and 9 in Carcinogenesis of Pancreatic Ductal Adenocarcinoma. Dis. Markers 2016, 2016, 9895721. [CrossRef] [PubMed]

216. Zhi, Y.-H.; Song, M.-M.; Wang, P.-L.; Zhang, T.; Yin, Z.-Y. Suppression of matrix metalloproteinase-2 via RNA interference inhibits pancreatic carcinoma cell invasiveness and adhesion. World J. Gastroenterol. 2009, 15, 1072-1078. [CrossRef] [PubMed]

217. Ellenrieder, V.; Alber, B.; Lacher, U.; Hendler, S.F.; Menke, A.; Boeck, W.; Wagner, M.; Wilda, M.; Friess, H.; Büchler, M.; et al. Role of MT-MMPs and MMP-2 in pancreatic cancer progression. Int. J. Cancer 2000, 85, 14-20. [CrossRef]

218. Grunwald, B.; Vandooren, J.; Gerg, M.; Ahomaa, K.; Hunger, A.; Berchtold, S.; Akbareian, S.; Schaten, S.; Knolle, P.; Edwards, D.R.; et al. Systemic Ablation of MMP-9 Triggers Invasive Growth and Metastasis of Pancreatic Cancer via Deregulation of IL6 Expression in the Bone Marrow. Mol. Cancer Res. 2016, 14, 1147-1158. [CrossRef] [PubMed]

219. Ferguson, T.A.; Muir, D. MMP-2 and MMP-9 Increase the Neurite-Promoting Potential of Schwann Cell Basal Laminae and Are Upregulated in Degenerated Nerve. Mol. Cell. Neurosci. 2000, 16, 157-167. [CrossRef] [PubMed]

220. Court, F.A.; Zambroni, D.; Pavoni, E.; Colombelli, C.; Baragli, C.; Figlia, G.; Sorokin, L.; Ching, W.; Salzer, J.L.; Wrabetz, L.; et al. MMP2-9 cleavage of dystroglycan alters the size and molecular composition of Schwann cell domains. J. Neurosci. 2011, 31, 12208-12217. [CrossRef]

221. Li, Z.J.; Cho, C.H. Neurotransmitters, more than meets the eye-Neurotransmitters and their perspectives in cancer development and therapy. Eur. J. Pharmacol. 2011, 667, 17-22. [CrossRef] [PubMed]

222. Kuol, N.; Stojanovska, L.; Apostolopoulos, V.; Nurgali, K. Crosstalk between cancer and the neuro-immune system. J. Neuroimmunol. 2018, 315, 15-23. [CrossRef]

223. Schuller, H.M. A new twist to neurotransmitter receptors and cancer. J. Cancer Metastasis Treat. $2017,3,71$. [CrossRef]

224. Entschladen, F.; Drell, T.L.; Lang, K.; Joseph, J.; Zaenker, K.S. Tumour-cell migration, invasion and metastasis: Navigation by neurotransmitters. Lancet Oncol. 2004, 5, 254-258. [CrossRef]

225. Babic, T.; Travagli, R.A. Neural Control of the Pancreas. Pancreapedia Exocrine Pancreas Knowl. Base 2016. [CrossRef]

226. Bockman, D.E. Nerves in the pancreas: What are they for? Am. J. Surg. 2007, 194, S61-S64. [CrossRef]

227. Guo, K.; Ma, Q.; Li, J.; Wang, Z.; Shan, T.; Li, W.; Xu, Q.; Xie, K. Interaction of the Sympathetic Nerve with Pancreatic Cancer Cells Promotes Perineural Invasion through the Activation of STAT3 Signaling. Mol. Cancer Ther. 2013, 12, 264-273. [CrossRef] [PubMed]

228. Weddle, D.L.; Tithoff, P.; Williams, M.; Schuller, H.M. beta-Adrenergic growth regulation of human cancer cell lines derived from pancreatic ductal carcinomas. Carcinogenesis 2001, 22, 473-479. [CrossRef] [PubMed]

229. Kim-Fuchs, C.; Le, C.P.; Pimentel, M.A.; Shackleford, D.; Ferrari, D.; Angst, E.; Hollande, F.; Sloan, E.K. Chronic stress accelerates pancreatic cancer growth and invasion: A critical role for beta-adrenergic signaling in the pancreatic microenvironment. Brain. Behav. Immun. 2014, 40,40-47. [CrossRef]

230. Schuller, H.M.; Al-Wadei, H.A. Neurotransmitter receptors as central regulators of pancreatic cancer. Future Oncol. 2010, 6, 221-228. [CrossRef]

231. Al-Wadei, M.H.; Al-Wadei,H.A.N.; Schuller, H.M. Gamma-amino butyric acid (GABA) prevents the induction of nicotinic receptor-regulated signaling by chronic ethanol in pancreatic cancer cells and normal duct epithelia. Cancer Prev. Res. 2013, 6, 139-148. [CrossRef]

232. Al-Wadei, H.A.; Al-Wadei, M.H.; Schuller, H.M. Prevention of pancreatic cancer by the beta-blocker propranolol. Anticancer Drugs 2009, 20, 477-482. [CrossRef]

233. Renz, B.W.; Takahashi, R.; Tanaka, T.; Macchini, M.; Hayakawa, Y.; Dantes, Z.; Maurer, H.C.; Chen, X.; Jiang, Z.; Westphalen, C.B.; et al. $\beta 2$ Adrenergic-Neurotrophin Feedforward Loop Promotes Pancreatic Cancer. Cancer Cell 2018, 33, 75-90. [CrossRef] [PubMed] 
234. Beg, M.S.; Gupta, A.; Sher, D.; Ali, S.; Khan, S.; Gao, A.; Stewart, T.; Ahn, C.; Berry, J.; Mortensen, E.M. Impact of Concurrent Medication Use on Pancreatic Cancer Survival-SEER-Medicare Analysis. Am. J. Clin. Oncol. 2018, 41, 766-771. [CrossRef] [PubMed]

235. Udumyan, R.; Montgomery, S.; Fang, F.; Almroth, H.; Valdimarsdottir, U.; Ekbom, A.; Smedby, K.E.; Fall, K. Beta-Blocker Drug Use and Survival among Patients with Pancreatic Adenocarcinoma. Cancer Res. 2017, 77, 3700-3707. [CrossRef] [PubMed]

236. Na, Z.; Qiao, X.; Hao, X.; Fan, L.; Xiao, Y.; Shao, Y.; Sun, M.; Feng, Z.; Guo, W.; Li, J.; et al. The effects of beta-blocker use on cancer prognosis: A meta-analysis based on 319,006 patients. Onco Targets Ther. 2018, 11, 4913-4944. [CrossRef] [PubMed]

237. Partecke, L.I.; Käding, A.; Trung, D.N.; Diedrich, S.; Sendler, M.; Weiss, F.; Kühn, J.-P.; Mayerle, J.; Beyer, K.; von Bernstorff, W.; et al. Subdiaphragmatic vagotomy promotes tumor growth and reduces survival via $\mathrm{TNF} \alpha$ in a murine pancreatic cancer model. Oncotarget 2017, 8, 22501-22512. [CrossRef] [PubMed]

238. Renz, B.W.; Tanaka, T.; Sunagawa, M.; Takahashi, R.; Jiang, Z.; Macchini, M.; Dantes, Z.; Valenti, G.; White, R.A.; Middelhoff, M.A.; et al. Cholinergic Signaling via Muscarinic Receptors Directly and Indirectly Suppresses Pancreatic Tumorigenesis and Cancer Stemness. Cancer Discov. 2018, 8, 1458-1473. [CrossRef] [PubMed]

239. De Couck, M.; Maréchal, R.; Moorthamers, S.; van Laethem, J.-L.; Gidron, Y. Vagal nerve activity predicts overall survival in metastatic pancreatic cancer, mediated by inflammation. Cancer Epidemiol. 2016, 40, 47-51. [CrossRef] [PubMed]

240. Friess, H.; Zhu, Z.; Liard, V.; Shi, X.; Shrikhande, S.V.; Wang, L.; Lieb, K.; Korc, M.; Palma, C.; Zimmermann, A.; et al. Neurokinin-1 receptor expression and its potential effects on tumor growth in human pancreatic cancer. Lab. Investig. 2003, 83, 731-742. [CrossRef]

241. Li, X.; Ma, G.; Ma, Q.; Li, W.; Liu, J.; Han, L.; Duan, W.; Xu, Q.; Liu, H.; Wang, Z.; et al. Neurotransmitter substance P mediates pancreatic cancer perineural invasion via NK-1R in cancer cells. Mol. Cancer Res. 2013, 11, 294-302. [CrossRef]

242. Muñoz, M.; Coveñas, R. Involvement of substance P and the NK-1 receptor in pancreatic cancer. World J. Gastroenterol. 2014, 20, 2321. [CrossRef]

243. Kirchgessner, A.L.; Gershon, M.D. Innervation of the pancreas by neurons in the gut. J. Neurosci. 1990, 10, 1626-1642. [CrossRef] [PubMed]

244. Bakst, R.L.; Lee, N.; He, S.; Chernichenko, N.; Chen, C.H.; Linkov, G.; Le, H.C.; Koutcher, J.; Vakiani, E.; Wong, R.J. Radiation impairs perineural invasion by modulating the nerve microenvironment. PLoS ONE 2012, 7, e39925. [CrossRef] [PubMed]

(C) 2019 by the authors. Licensee MDPI, Basel, Switzerland. This article is an open access article distributed under the terms and conditions of the Creative Commons Attribution (CC BY) license (http://creativecommons.org/licenses/by/4.0/). 